\title{
Обзоры
}

Пространственная Экономика

2012. № 2. C. 89-127

УДК 338.1(571.6)

О. М. Прокапало, А. Г. Исаев, $\Delta$. В. Суслов,

Е. И. $\Delta$ еваева, Т. Е. Котова

ЭКОНОМИЧЕСКАЯ

KOHЬЮНКTYPA

B $\triangle$ АА ВНEBOCTOЧHOM

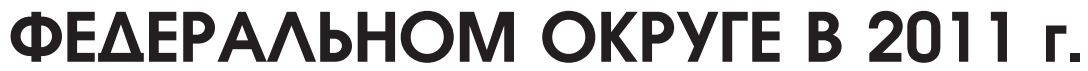

На основе официальной оперативной статистической информации за 2011 г. оценены тенденции социально-экономического развития Дальневосточного федерального округа. Рассмотрены общеэкономическая ситуация, текущая ситуация в сфере производства товаров и услуг, социальной сфере, параметры внешнеэкономического сотрудничества.

ВРП, промышленность, финансы, инфляция, доходы населения, рынок труда, иностранные инвестиции, внешняя торговля, Дальневосточный федеральный округ.

\section{ОБЩЕЭКОНОМИЧЕСКАЯ СИТУАЦИЯ}

Экономическое и социальное развитие Дальневосточного федерального округа (ДФО) в посткризисный период демонстрирует устойчивый рост на фоне незначительного оживления российской экономики. Динамика сводных макропоказателей экономической активности в ДФО заметно опережает среднероссийские значения (табл. 1).

() Прокапало О. М., Исаев А. Г., Суслов Д. В., Деваева Е. И., Котова Т. Е., 2012

Статья подготовлена при поддержке гранта РГНФ № 11-02-00566а, проектов № 12-I-П31-02, № 12-I-П31-03. 
Динамика основных показателей развития экономики РФ и ДФО,

Таблица 1 в \% к предыдущему году

\begin{tabular}{l|c|c|c|c|c|c|c|c}
\hline \multirow{2}{*}{\multicolumn{1}{c|}{ Показатель }} & \multicolumn{2}{|c|}{2009} & \multicolumn{2}{c|}{2010} & \multicolumn{2}{c|}{2011} & \multicolumn{2}{c}{$\begin{array}{c}\text { Справочно } \\
2011 \text { в } \% \\
\text { к } 2008\end{array}$} \\
\cline { 2 - 10 } & РФ & ДФО & РФ & ДФО & РФ & ДФО & РФ & ДФО \\
\hline $\begin{array}{l}\text { Валовой внутренний } \\
\text { (региональный) } \\
\text { продукт }\end{array}$ & 92,2 & 101,5 & 104,3 & 106,5 & 104,3 & 105,01 & 100,3 & 113,5 \\
\hline $\begin{array}{l}\text { Индекс промышленного } \\
\text { производства }\end{array}$ & 90,7 & 107,6 & 108,2 & 106,5 & 104,7 & 107,5 & 102,7 & 123,2 \\
\hline $\begin{array}{l}\text { Инвестиции в основной } \\
\text { капитал }\end{array}$ & 84,3 & 107,1 & 106,0 & 97,9 & 108,3 & 121,4 & 96,8 & 127,3 \\
\hline $\begin{array}{l}\text { Грузооборот по всем видам } \\
\text { транспорта }\end{array}$ & 89,8 & 102,8 & 106,9 & 122,7 & 103,4 & 105,0 & 99,3 & 132,4 \\
\hline \begin{tabular}{l} 
Экспорт \\
\hline $\begin{array}{l}\text { Ввод в действие жилых } \\
\text { домов }\end{array}$
\end{tabular}$\quad 94,5$ & 85,1 & 131,5 & 155,4 & 131,9 & н. д. & 111,9 & н. д. \\
\hline $\begin{array}{l}\text { Реальная среднемесячная } \\
\text { заработная плата }\end{array}$ & 96,5 & 98,8 & 105,2 & 104,5 & 104,2 & 105,1 & 105,8 & 108,5 \\
\hline
\end{tabular}

Примечания: 1 - предварительные данные; 2 - агрегированный индекс производства по видам деятельности «Добыча полезных ископаемых», «Обрабатывающие производства», «Производство и распределение электроэнергии, газа и воды».

Источники: [6; 13; 15; 17].

Высокая скорость восстановительного подъема дальневосточной экономики, как отмечалось ранее [14], связана со структурными особенностями производства и инвестиционными предпочтениями государства и частных инвесторов. Результатом этого явилось то, что в 2011 г. процесс устойчивого развития экономики ДФО сохранялся, причем относительно 2008 г. демонстрировал весьма сильный рост. Это тем более заметно на фоне восстановительной динамики российской экономики, в которой объемы в строительстве, на транспорте, инвестиционной активности в 2011 г. так и не достигли уровня 2008 г.

Важной составляющей экономического роста дальневосточной экономики является промышленность ${ }^{1}$, доля которой в структуре валовой добавленной стоимости превышает 36\%. Именно успехи в промышленности в большей степени генерируют устойчивое поступательное развитие экономики округа в посткризисный период (табл. 2).

\footnotetext{
1 Агрегированный показатель по видам деятельности «Добыча полезных ископаемых», «Обрабатывающие производства», «Производство и распределение электроэнергии, газа и воды».
} 
Динамика промышленного производства, в \% к предыдущему году

Таблица 2

\begin{tabular}{l|c|c|c|c}
\hline \multicolumn{1}{c|}{ Территория } & 2009 & 2010 & 2011 & $\begin{array}{c}\text { Справочно 2011 } \\
\text { в \% к 2008 }\end{array}$ \\
\hline Российская Федерация & 90,7 & 108,2 & 104,7 & 102,7 \\
\hline ДФО & 107,6 & 106,5 & 107,5 & 123,2 \\
\hline Республика Саха (Якутия) & 86,4 & 118,0 & 110,5 & 112,7 \\
\hline Камчатский край & 99,8 & 108,6 & 120,1 & 130,2 \\
\hline Приморский край & 97,3 & 113,4 & 117,4 & 129,5 \\
\hline Хабаровский край & 93,2 & 121,3 & 112,9 & 127,6 \\
\hline Амурская область & 111,4 & 100,1 & 118,0 & 131,6 \\
\hline Магаданская область & 105,8 & 103,3 & 107,1 & 117,1 \\
\hline Сахалинская область & 126,6 & 100,0 & 102,3 & 129,5 \\
\hline ЕАО & 81,2 & 102,3 & 100,4 & 83,4 \\
\hline ЧАО & 116,3 & 90,3 & 93,6 & 98,3 \\
\hline
\end{tabular}

Источники: [15; 17].

Рост промышленного производства в 2011 г. отмечен практически по всем (кроме Чукотского автономного округа (ЧАО) территориям ДФО, причем в большинстве регионов темп роста превышал среднероссийский уровень.

В настоящее время в ДФО сохраняется тенденция увеличения добывающего сектора в общем объеме промышленного производства. Если в целом по России структура производства в течение 2005-2011 гг. остается практически неизменной, то на Дальнем Востоке России доля добывающих отраслей в общем объеме промышленного производства увеличилась в 1,4 раза. Ввод в эксплуатацию новых и наращивание объемов на существующих месторождениях по добыче минерально-сырьевых и топливно-энергетических ресурсов заметно утяжелили структуру экономики в Амурской и Сахалинской областях, Чукотском автономном округе (табл. 3). Высокий удельный вес в экономике региона добывающего сектора, в котором падение производства было минимальным, позволил значительно снизить восстановительный период и нивелировать последствия кризисных шоков.

По динамике ряда показателей можно судить о послекризисном восстановлении спроса на продукцию промышленности Дальнего Востока. Теоретически повышение спроса выражается в повышении цен на продукцию предприятий. Однако на практике повышение цен может быть вызвано стремлением убыточных предприятий покрыть возрастающие производственные издержки (подробнее см. [3]). С другой стороны, повышение цены продукции, вызванное ростом спроса на нее, должно выражаться в увеличении доходов факторов производства. 
Динамика структуры промышленного производства (по объему отгруженных товаров собственного производства, выполненных работ и услуг собственными силами), \%

\begin{tabular}{l|c|c|c|c|c|c}
\hline \multirow{2}{*}{ Территория } & \multicolumn{2}{|c|}{$\begin{array}{c}\text { Добыча полезных } \\
\text { ископаемых }\end{array}$} & \multicolumn{2}{c|}{$\begin{array}{c}\text { Обрабатывающие } \\
\text { производства }\end{array}$} & \multicolumn{2}{c}{$\begin{array}{c}\text { Производство } \\
\text { г распрделение э/э, и воды }\end{array}$} \\
\cline { 2 - 7 } & 2005 & 2011 & 2005 & 2011 & 2005 & 2011 \\
\hline Российская Федерация & 22,5 & 23,4 & 65,1 & 65,0 & 12,4 & 11,6 \\
\hline ДФО & 45,5 & 63,6 & 30,2 & 22,2 & 24,3 & 14,2 \\
\hline Республика Саха (Якутия) & 77,6 & 79,9 & 9,7 & 7,5 & 12,7 & 12,6 \\
\hline Камчатский край & 12,3 & 11,2 & 41,4 & 60,1 & 46,4 & 28,8 \\
\hline Приморский край & 9,4 & 7,9 & 52,8 & 63,5 & 37,7 & 28,6 \\
\hline Хабаровский край & 17,4 & 14,8 & 56,4 & 61,4 & 26,3 & 23,9 \\
\hline Амурская область & 25,0 & 51,0 & 27,2 & 23,1 & 47,9 & 25,9 \\
\hline Магаданская область & 68,9 & 74,4 & 12,7 & 7,0 & 18,4 & 18,6 \\
\hline Сахалинская область & 65,8 & 92,5 & 21,7 & 4,6 & 12,6 & 2,9 \\
\hline ЕАО & 6,5 & 6,7 & 69,2 & 47,8 & 24,3 & 45,5 \\
\hline ЧАО & 41,2 & 81,9 & 13,1 & 1,7 & 45,6 & 16,4 \\
\hline
\end{tabular}

Источники: [15; 17; 18].

Разность относительных изменений среднемесячной заработной платы

Таблица 4 в промышленности и по экономике региона в целом, \%

\begin{tabular}{l|c|c|c|c}
\hline \multirow{2}{*}{\multicolumn{1}{c|}{ Территория }} & \multicolumn{4}{|c}{$\Delta W_{I} / W_{I}-\Delta W_{R} / W_{R}$} \\
\cline { 2 - 5 } & \multicolumn{2}{|c}{$\begin{array}{c}\text { добыча полезных } \\
\text { ископаемых }\end{array}$} & \multicolumn{2}{c}{$\begin{array}{c}\text { обрабатывающие } \\
\text { производства }\end{array}$} \\
\cline { 2 - 5 } & $2009 / 2008$ & $2011 / 2009$ & $2009 / 2008$ & $2011 / 2009$ \\
\hline ДФО & $-3,3$ & 10,3 & $-3,2$ & 13,5 \\
\hline Республика Саха (Якутия) & $-10,2$ & 16,1 & $-7,7$ & 8,3 \\
\hline Камчатский край & $-16,5$ & 17,7 & $-5,9$ & 37,3 \\
\hline Приморский край & $-4,2$ & 7,7 & $-2,9$ & 10 \\
\hline Хабаровский край & $-1,7$ & 5,9 & $-8,6$ & 13,1 \\
\hline Амурская область & 1,7 & 14,4 & 17,9 & -18 \\
\hline Магаданская область & 2,3 & 37,5 & 6,2 & 8,7 \\
\hline Сахалинская область & 19,2 & $-2,8$ & 2,6 & 2,8 \\
\hline ЕАО & 10,4 & 6,5 & $-11,4$ & $-3,2$ \\
\hline ЧАО & $-3,2$ & 18,6 & 3,3 & $-6,7$ \\
\hline
\end{tabular}

Примечание. $\Delta W_{I} / W_{I}$ - темп прироста среднемесячной заработной платы в промышленности, \%; $\Delta W_{R} / W_{R}-$ темп прироста среднемесячной заработной платы по экономике региона в целом, \%. 
Следовательно, об изменении спроса можно косвенно судить по относительному изменению среднемесячной заработной платы в сравниваемых отраслях экономики [19]. В таблице 4 представлена разность между процентным изменением среднемесячных трудовых доходов в добывающей и обрабатывающей промышленности ДФО и процентным изменением заработной платы по экономике региона в целом. Таким образом, данные из таблицы характеризуют не абсолютный рост спроса на продукцию добывающей и обрабатывающей промышленности субъектов РФ, а лишь относительный в сравнении с остальными секторами экономики в целом.

Из таблицы 4 следует, что в 2009 г. в ДФО прирост доходов труда в промышленности отставал от прироста доходов труда по экономике в целом, что может свидетельствовать об ухудшении условий спроса для данного сектора экономики в период кризиса. Однако тенденции 2010-2011 гг. показывают, что как добывающий, так и обрабатывающий сектора промышленности ДФО в целом преодолели последствия ухудшения рыночной конъюнктуры.

В 2010-2011 гг. сохраняется тенденция наращивания объемов производства в обрабатывающем секторе экономики региона. Абсолютные значения годовых темпов роста значительно опережают показатели в добывающих отраслях промышленности. Это можно оценивать двояко: как фактор интенсивного поступательного развития производства, так и низкой базой для сравнения, обусловленной значительным сокращением выпуска продукции в период кризисного спада. Однако, учитывая, что эта отрасль оказалась наиболее пострадавшим от кризиса сегментом экономики, а также ее сравнительно невысокий удельный вес в структуре промышленности ДФО (уменьшение с 30,3 \% в 2005 г. до 22,2 \% в 2011 г. (см. табл. 3), говорить о растущей диверсификации промышленности Дальнего Востока не приходится.

В минувшем году рост в обрабатывающем секторе экономики округа $(114,6 \%)$ в основном был обеспечен высокими темпами роста в Приморском и Хабаровском краях (122,5 и 117,3\% соответственно) и Амурской области $(111,0 \%)$ (табл. 4). Следует отметить, что в Хабаровском и Приморском краях сформировались крупномасштабные производства в сфере гражданского машиностроения (авиастроение и автомобилестроение).

Устойчивое развитие в обрабатывающем секторе Приморского края связано в основном с предприятиями по производству транспортных средств и оборудования; готовых металлических изделий; обработкой древесины и производством изделий из дерева; производством прочих неметаллических минеральных продуктов, которые обеспечили более $82 \%$ прироста промышленного производства [2]. В Хабаровском крае высокие показатели развития обрабатывающего сектора обеспечены предприятиями авиа- и судостроения, 
№ 22012

рост производства на которых относительно 2010 г. составил соответственно 17 и 140\%. Важной составляющей наращивания объемов производства является получение заказов на поставку продукции военного и гражданского назначения. Так, на судостроительных предприятиях края оборонный заказ увеличился в 1,5 раза относительно 2010 г. (2,7 раза по сравнению с 2009 г.), а в Комсомольском-на-Амуре авиационном производственном объединении производство по государственному оборонному заказу возросло на 27\%. В минувшем году было передано по коммерческим контрактам четыре первых самолета Superjet 100 [16].

Таблица 5

Индекс промышленного производства по видам экономической деятельности, 2011 г. в \% к 2010 г.

\begin{tabular}{l|c|c|c}
\hline \multicolumn{1}{c|}{ Территория } & $\begin{array}{c}\text { Добыча полезных } \\
\text { ископаемых }\end{array}$ & $\begin{array}{c}\text { Обрабатывающие } \\
\text { производства }\end{array}$ & $\begin{array}{c}\text { Производство } \\
\text { элекределенение } \\
\text { газа и воды }\end{array}$ \\
\hline Российская Федерация & 101,9 & 106,5 & 100,1 \\
\hline ДФО & 106,6 & 114,6 & 99,8 \\
\hline Республика Саха (Якутия) & 112,1 & 102,2 & 103,9 \\
\hline Камчатский край & 177,9 & 104,3 & 101,2 \\
\hline Приморский край & 113,0 & 122,5 & 103,3 \\
\hline Хабаровский край & 106,0 & 117,3 & 101,8 \\
\hline Амурская область & 138,5 & 111,0 & 93,0 \\
\hline Магаданская область & 109,9 & 98,2 & 101,0 \\
\hline Сахалинская область & 103,0 & 93,4 & 93,1 \\
\hline ЕАО & 118,9 & 108,9 & 87,2 \\
\hline ЧАО & 90,4 & 97,8 & 96,0 \\
\hline
\end{tabular}

Источник: [17].

Рост в добывающем секторе ДФО в абсолютном выражении выглядит скромнее (106,6\%). Несмотря на это, именно этот сектор в настоящее время сохраняет лидирующие позиции в формировании общепромышленного регионального роста. Так, вклад в общий рост промышленного производства сферы деятельности «Добыча полезных ископаемых» составил более $50 \%$. Положительная динамика в основном связана с увеличением производства в Амурской области (138,5\%), Республике Саха (Якутия) (112,1\%). Значительный рост производства в Камчатском крае $(177,9 \%)$ не в состоянии был значительно скорректировать общерегиональный темп роста в связи с тем, что в структуре добывающего сектора ДФО доля Камчатского края составляет немногим более $10 \%$ (см. табл. 3). 


\section{Финансы}

Продолжающееся в 2011 г. восстановление экономики обеспечило улучшение финансового состояния предприятий региона. В январе - ноябре 2011 г. сальдированный финансовый результат организаций в целом по ДФО в действующих ценах составил 340,5 млрд руб., что на 46,1\% выше, чем за аналогичный период предыдущего года. По величине сальдированной прибыли в тройку лидеров входят Сахалинская область, Республика Саха (Якутия), Чукотский автономный округ (табл. б).

Финансовые результаты деятельности организаций

Таблица 6 за январь - ноябрь 2011 г.

\begin{tabular}{|c|c|c|c|c|c|}
\hline \multirow[b]{2}{*}{ Территория } & \multicolumn{2}{|c|}{$\begin{array}{c}\text { Сальдо прибылей (+) } \\
\text { и убытков (-) }\end{array}$} & \multicolumn{2}{|c|}{ Прибыль } & \multirow{2}{*}{$\begin{array}{c}\text { Удельный вес } \\
\text { убыточных } \\
\text { предприятий, } \\
\%\end{array}$} \\
\hline & млн руб. & $\begin{array}{c}\text { в \% к } \\
\text { январю - } \\
\text { ноябрю } \\
2010 \text { г. * }\end{array}$ & млн руб. & $\begin{array}{c}\text { в \% к } \\
\text { январю - } \\
\text { ноябрю } \\
2010 \text { г. * }\end{array}$ & \\
\hline ДФО & 340576,8 & $\ldots$ & 395950,7 & 145,9 & $\ldots$ \\
\hline $\begin{array}{l}\text { Республика Саха } \\
\text { (Якутия) }\end{array}$ & 67481,1 & в $2,2 \mathrm{p}$. & 74181,3 & в $2 \mathrm{p}$. & 34,7 \\
\hline Камчатский край & 2499,9 & 69,9 & 6296,4 & 106,4 & 35,8 \\
\hline Приморский край & 14829,5 & 55,3 & 25427,2 & 77,4 & 28,6 \\
\hline Хабаровский край & 14935,7 & 121,4 & 30390,5 & 114,9 & 35,3 \\
\hline Амурская область & 10223,5 & 57,1 & 18695,3 & 96,5 & 31,4 \\
\hline Магаданская область & 6285,5 & 94,1 & 8537,8 & 116,9 & 31,0 \\
\hline Сахалинская область & 208435,8 & 172,9 & 213240,7 & 172,5 & 36,1 \\
\hline EAO & $-491,6$ & - & 253,8 & 53,7 & 57,4 \\
\hline ЧАО & 16377,4 & 101,0 & 18927,7 & 103,0 & 42,9 \\
\hline
\end{tabular}

Примечание. * В фактических ценах.

Источник: [13].

Как и в предыдущие годы, высокоприбыльными остаются предприятия добывающего сектора, доля которых в суммарном сальдируемом показателе составляет более $85 \%$ (табл. 7). Именно высокий удельный вес предприятий, занятых добычей полезных ископаемых в Республике Саха (Якутия) и Сахалинской области, обеспечил им лидирующие позиции в увеличении финансовых результатов. В Чукотском автономном округе высокий суммарный финансовый результат был связан с работой предприятий добывающего сектора и сферы торговли. 
22012

Таблица 7

Сальдированный финансовый результат организаций по основным видам экономической деятельности в январе - ноябре 2011 г., млн руб.

\begin{tabular}{|c|c|c|c|c|c|c|c|}
\hline Территория & $\begin{array}{c}\text { Добыча } \\
\text { полез- } \\
\text { ных } \\
\text { иско- } \\
\text { паемых }\end{array}$ & $\begin{array}{c}\text { Обра- } \\
\text { баты- } \\
\text { вающие } \\
\text { произ- } \\
\text { водства }\end{array}$ & $\begin{array}{c}\text { Производ- } \\
\text { ство и рас- } \\
\text { пределение } \\
\text { электро- } \\
\text { энергии, } \\
\text { газа и воды }\end{array}$ & $\begin{array}{c}\text { Сельское } \\
\text { хозяй- } \\
\text { ство, } \\
\text { охота } \\
\text { и лесное } \\
\text { хозяйство }\end{array}$ & $\begin{array}{c}\text { Рыбо- } \\
\text { ловство, } \\
\text { рыбо- } \\
\text { водство }\end{array}$ & $\begin{array}{c}\text { Строи- } \\
\text { тель- } \\
\text { ство }\end{array}$ & $\begin{array}{c}\text { Транс- } \\
\text { порт и } \\
\text { связь }\end{array}$ \\
\hline $\begin{array}{l}\text { Республика } \\
\text { Саха (Якутия) }\end{array}$ & $\begin{array}{c}67494,7 \\
(35,6)\end{array}$ & $\begin{array}{l}-109,4 \\
(52,6)\end{array}$ & $\begin{array}{c}-2598,6 \\
(46,2)\end{array}$ & $\begin{array}{l}144,3 \\
(36,4)\end{array}$ & $\begin{array}{l}-620,0 \\
(100,0)\end{array}$ & $\begin{array}{l}435,8 \\
(23,4)\end{array}$ & $\begin{array}{l}289,8 \\
(36,4)\end{array}$ \\
\hline $\begin{array}{l}\text { Камчатский } \\
\text { край }\end{array}$ & $\begin{array}{l}466,6 \\
(83,3)\end{array}$ & $\begin{array}{l}1513,8 \\
(20,8)\end{array}$ & $\begin{array}{c}-1230,6 \\
(52,4)\end{array}$ & $\begin{array}{l}130,1 \\
(11,1)\end{array}$ & $\begin{array}{l}1542,0 \\
(25,0)\end{array}$ & $\begin{array}{c}18,4 \\
(23,1)\end{array}$ & $\begin{array}{l}-520,5 \\
(52,6)\end{array}$ \\
\hline $\begin{array}{l}\text { Приморский } \\
\text { край }\end{array}$ & $\begin{array}{l}2205,8 \\
(36,4) \\
\end{array}$ & $\begin{array}{l}1290,4 \\
(28,5)\end{array}$ & $\begin{array}{c}-713,9 \\
(46,2) \\
\end{array}$ & $\begin{array}{l}375,3 \\
(35,9) \\
\end{array}$ & $\begin{array}{c}3253,3 \\
(5,0)\end{array}$ & $\begin{array}{c}-351,7 \\
(36,7) \\
\end{array}$ & $\begin{array}{l}7330,6 \\
(27,7) \\
\end{array}$ \\
\hline $\begin{array}{l}\text { Хабаровский } \\
\text { край }\end{array}$ & $\begin{array}{l}3149,6 \\
(41,2) \\
\end{array}$ & $\begin{array}{l}-459,0 \\
(38,2) \\
\end{array}$ & $\begin{array}{l}1000,9 \\
(59,6)\end{array}$ & $\begin{array}{l}534,5 \\
(36,4) \\
\end{array}$ & $\begin{array}{l}290,3 \\
(50,0) \\
\end{array}$ & $\begin{array}{l}1939,8 \\
(31,0)\end{array}$ & $\begin{array}{l}3299,7 \\
(32,1) \\
\end{array}$ \\
\hline $\begin{array}{l}\text { Амурская } \\
\text { область }\end{array}$ & $\begin{array}{c}13057,2 \\
(22,2) \\
\end{array}$ & $\begin{array}{l}478,0 \\
(21,1) \\
\end{array}$ & $\begin{array}{c}-980,8 \\
(64,0) \\
\end{array}$ & $\begin{array}{l}1041,8 \\
(27,9)\end{array}$ & - & $\begin{array}{l}1186,0 \\
(23,9)\end{array}$ & $\begin{array}{l}488,4 \\
(54,5) \\
\end{array}$ \\
\hline $\begin{array}{l}\text { Магаданская } \\
\text { область }\end{array}$ & $\begin{array}{r}4402,3 \\
(31,8) \\
\end{array}$ & $\begin{array}{l}256,0 \\
(20,0)\end{array}$ & $573,4(33,3)$ & $\begin{array}{c}-2,2 \\
(66,7)\end{array}$ & $\begin{array}{c}21,7 \\
(33,3) \\
\end{array}$ & $\begin{array}{l}293,7 \\
(20,0) \\
\end{array}$ & $\begin{array}{l}196,1 \\
(22,2) \\
\end{array}$ \\
\hline $\begin{array}{l}\text { Сахалинская } \\
\text { область }\end{array}$ & $\begin{array}{c}204293,7 \\
(47,8)\end{array}$ & $\begin{array}{l}1341,0 \\
(22,2)\end{array}$ & $96,4(64,3)$ & $\begin{array}{l}288,8 \\
(12,5)\end{array}$ & $\begin{array}{l}354,8 \\
(40,0)\end{array}$ & $\begin{array}{c}-603,4 \\
(35,7)\end{array}$ & $\begin{array}{c}2504,0 \\
(27,3)\end{array}$ \\
\hline EAO & $\begin{array}{c}-258,7 \\
(75,0) \\
\end{array}$ & $\begin{array}{l}-101,6 \\
(62,5)\end{array}$ & $50,9(66,7)$ & $\begin{array}{c}23,5 \\
(46,2)\end{array}$ & - & $\begin{array}{c}-269,5 \\
(60,0) \\
\end{array}$ & $\begin{array}{c}1,9 \\
(71,4)\end{array}$ \\
\hline ЧАО & $\begin{array}{c}9434,7 \\
(28,6)\end{array}$ & $\begin{array}{l}-52,6 \\
(50,0)\end{array}$ & $\begin{array}{c}-1228,8 \\
(75,0)\end{array}$ & $\begin{array}{l}111,3 \\
(21,1)\end{array}$ & $\begin{array}{l}-59,9 \\
(66,7) \\
\end{array}$ & $\begin{array}{c}266,2 \\
(\ldots)\end{array}$ & $\begin{array}{l}-41,4 \\
(50,0)\end{array}$ \\
\hline
\end{tabular}

Примечание. В скобках - удельный вес убыточных предприятий, \%.

Источник: [13].

В минувшем году не произошло существенных изменений в количественной структуре убыточных предприятий, удельный вес которых в большинстве территорий округа составляет 31-36\%, а в Чукотском автономном округе и Еврейской автономной области доля убыточных предприятий еще выше (42,9 и 57,4\% соответственно). Высокий удельный вес убыточных предприятий сохраняется и в отраслях, которые являются драйверами регионального роста. Так, в добывающем секторе ДФО доля убыточных предприятий составляла 22,2\% в Амурской области (наименьший показатель) и 83,3\% в Камчатском крае (наивысший показатель). И даже в регионах, финансовое благополучие которых непосредственно связано с добычей минерально-сырьевых и топливно-энергетических ресурсов (Сахалинская область, Республика Саха (Якутия), Амурская область), удельный вес убыточных предприятий составляет 47,8; 35,6 и 22,2\% соответственно. 


\section{Инвестиции}

Одним из факторов стабильного развития экономики Дальнего Востока выступают инвестиционные ресурсы. В 2011 г. на развитие экономики и социальной сферы ДФО за счет всех источников финансирования было использовано 1013,9 млрд руб. капитальных вложений (рост относительно 2010 г. 121,4\%). За период 2009-2011 гг. в экономику округа было вложено 2426 млрд руб. По интенсивности наращивания инвестиций в этот период Дальний Восток сохранял лидирующие позиции среди федеральных округов Российской Федерации (рис. 1).

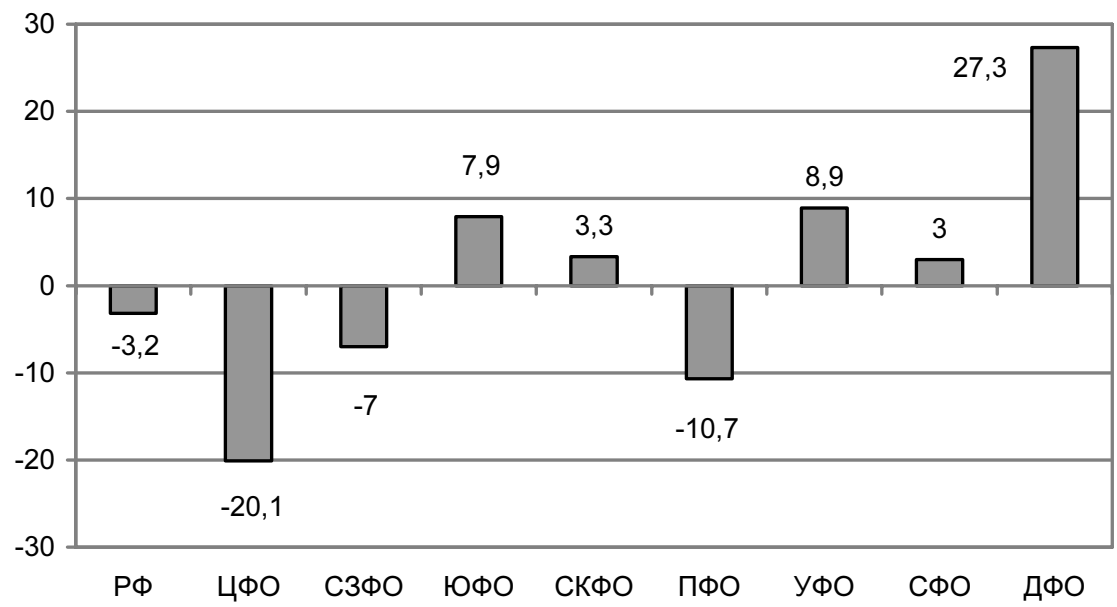

Puc. 1. Темп прироста (снижения) объема инвестиций по РФ и федеральным округам в 2011 г., \% к 2008 г.

Стабильное наращивание объемов инвестиционных ресурсов связано с реализацией политики государства и бизнеса по созданию на Дальнем Востоке России надежной опорной транспортной и энергетической инфраструктуры, направленной на преодоление существующих ограничений по интенсивной эксплуатации действующих и разработку новых месторождений минерально-сырьевых и топливно-энергетических ресурсов региона, а также наращиванию экспортных поставок в страны Азиатско-Тихоокеанского региона.

Территориальное распределение инвестиционных ресурсов не претерпело существенных изменений: основной объем инвестиций, совокупная доля которых в общем объеме в отдельные годы составляла 79,2-81,3\%, аккумулировался в четырех регионах (Республика Саха (Якутия), Приморский и Хабаровский края, Сахалинская область) (табл. 8). Именно на этих территориях реализуются высокозатратные инвестиционные проекты: нефтепровод 
№ 22012

Восточная Сибирь - Тихий океан, объекты саммита АТЭС в г. Владивостоке, ресурсные проекты Южной Якутии, авто- и железнодорожная сеть федерального значения.

Территориальная структура инвестиций в основной капитал

Таблица 8 в 2009-2011 гг., \%

\begin{tabular}{l|c|c|c}
\hline \multicolumn{1}{c|}{ Территория } & 2009 & 2010 & 2011 \\
\hline ДФО, млрд руб. & 686,1 & 725,7 & 1013,9 \\
\hline Республика Саха (Якутия) & 28,1 & 16,2 & 16,4 \\
\hline Камчатский край & 3,6 & 4,1 & 3,3 \\
\hline Приморский край & 21,8 & 27,7 & 27,5 \\
\hline Хабаровский край & 14,1 & 18,1 & 17,4 \\
\hline Амурская область & 9,6 & 10,9 & 12,2 \\
\hline Магаданская область & 2,2 & 1,9 & 1,9 \\
\hline Сахалинская область & 17,3 & 18,0 & 17,9 \\
\hline ЕАО & 1,2 & 2,6 & 2,6 \\
\hline ЧАО & 2,2 & 0,6 & 0,9 \\
\hline
\end{tabular}

Источник: рассчитано по: $[15 ; 17 ; 18]$.

В структуре инвестиций в основной капитал по источникам финансирования в целом по ДФО доля собственных средств невысока и составляла $22,4 \%$ и сократилась по сравнению с 2010 г. на 5,7 п. п. Средства, выделяемые из федерального бюджета, составляли 15,5\% в целом по ДФО и сократились по сравнению с 2010 г. на 2,5 п. п. Значительный объем федеральных ресурсов был использован в Магаданской области $(36,3 \%$ общего объема инвестиций), Приморском крае $(32,1 \%)$, Чукотском автономном округе $(31,1 \%)$.

\section{Инфляция}

В декабре 2011 г. инфляция на потребительском рынке ДФО составила $6,8 \%$, что ниже уровня 2009-2010 гг. на 2,9 и 0,9 п. п. соответственно. Необходимо отметить, что в 2011 г. ДФО потерял лидерство по минимальному значению данного показателя среди федеральных округов РФ, которое было отмечено в 2010 г. В 2011 г. индекс потребительской инфляции был на 0,6 п. п. выше среднероссийского показателя и наивысшим по сравнению с другими федеральными округами РФ. По территориям округа лишь в трех (ЧАО, Приморский и Хабаровский края) значение показателя не превышало среднероссийский уровень, а наивысшее отмечено в Магаданской области и ЕАО (109,2 и 108,9\% соответственно) (табл. 9). 
Индекс потребительских цен, декабрь к декабрю предыдущего года, \%

\begin{tabular}{l|c|c|c}
\hline \multicolumn{1}{c|}{ Территория } & 2009 & 2010 & 2011 \\
\hline Российская Федерация & 108,8 & 108,8 & 106,1 \\
\hline ДФО & 109,7 & 107,7 & 106,8 \\
\hline Республика Саха (Якутия) & 108,2 & 106,0 & 107,0 \\
\hline Камчатский край & 110,7 & 110,2 & 105,8 \\
\hline Приморский край & 109,5 & 107,0 & 105,6 \\
\hline Хабаровский край & 109,5 & 108,1 & 107,9 \\
\hline Амурская область & 109,6 & 109,4 & 107,6 \\
\hline Магаданская область & 113,4 & 108,5 & 109,2 \\
\hline Сахалинская область & 110,7 & 110,0 & 106,4 \\
\hline ЕАО & 112,2 & 109,5 & 108,9 \\
\hline ЧАО & 117,2 & 101,4 & 105,4 \\
\hline
\end{tabular}

Источники: [15; 17].

В течение 2011 г. инфляционные процессы можно охарактеризовать как умеренно поступательные. Рост цен продолжался в течение всего года, но с замедлением темпа относительно предыдущего года. На траекторию инфляции в январе и мае в значительной мере повлияла динамика цен на услуги, прирост которых относительно предыдущего периода составил 3,5 и 1,8\% соответственно (рис. 2).

К предыдущему месяцу

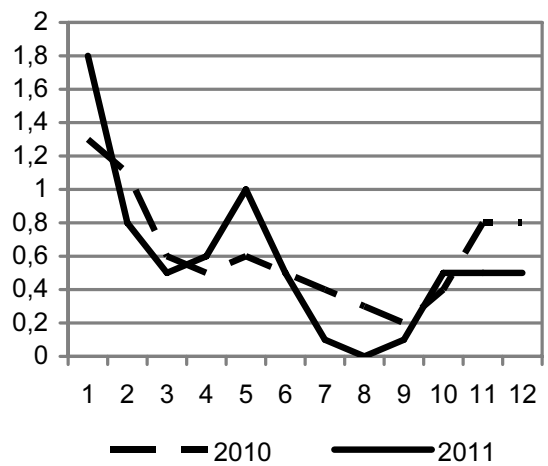

К декабрю предыдущего года

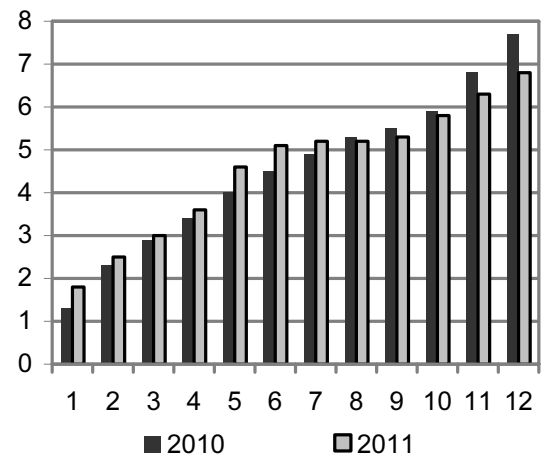

Puc. 2. Инфляция на потребительском рынке ДФО, прирост цен, \%

Снижение темпов роста инфляции связано с замедлением роста цен на продовольственные товары, сложившимся во многом из-за эффекта высокой базы сравнения. Рост цен на продовольственные товары в 2011 г. соста- 
№ 22012

вил 106,0\% против 109,3\% в 2010 г. Замедление роста цен на продовольствие началось уже с мая, которое с июня по сентябрь перешло в дефляцию. Положительную роль в снижении темпов роста цен на продовольственные товары в этот период сыграли принятые Правительством РФ меры по преодолению дисбаланса на рынке зерновых культур и стимулирование импорта плодоовощной продукции. Также сказалось начавшееся снижение мировых цен на зерно, сахар и другие продовольственные товары [10].

Цены на непродовольственные товары увеличились до 106,3\% против 105,1\% в 2010 г. Отмечался рост цен на автомобильный бензин в связи с ростом цен на нефтяные товары на мировых рынках, табачные изделия в связи с увеличением акциза с начала года, строительные материалы в связи с ростом отпускных цен. При этом на большинство товаров рост цен практически не превышал прошлогодний, сдерживаемый увеличением предложения импорта товаров при одновременном укреплении курса рубля.

Рост цен и тарифов на платные услуги населению остался практически на уровне прошлого года (108,7\% в 2011 г. против 108,9\% в 2010 г.) и незначительно повлиял на рост потребительской инфляции. На сдерживание роста цен повлияло усиление контроля со стороны Правительства РФ за тарифообразованием в субъектах Федерации, сохраняющаяся жесткая тарифная политика на отпускаемые для населения товары и услуги субъектов естественных монополий. В 2011 г. наибольший прирост цен на услуги населению был в Магаданской области (14,4\%), наименьший - в Чукотском автономном округе $-4,0 \%$ (рuс. 3).

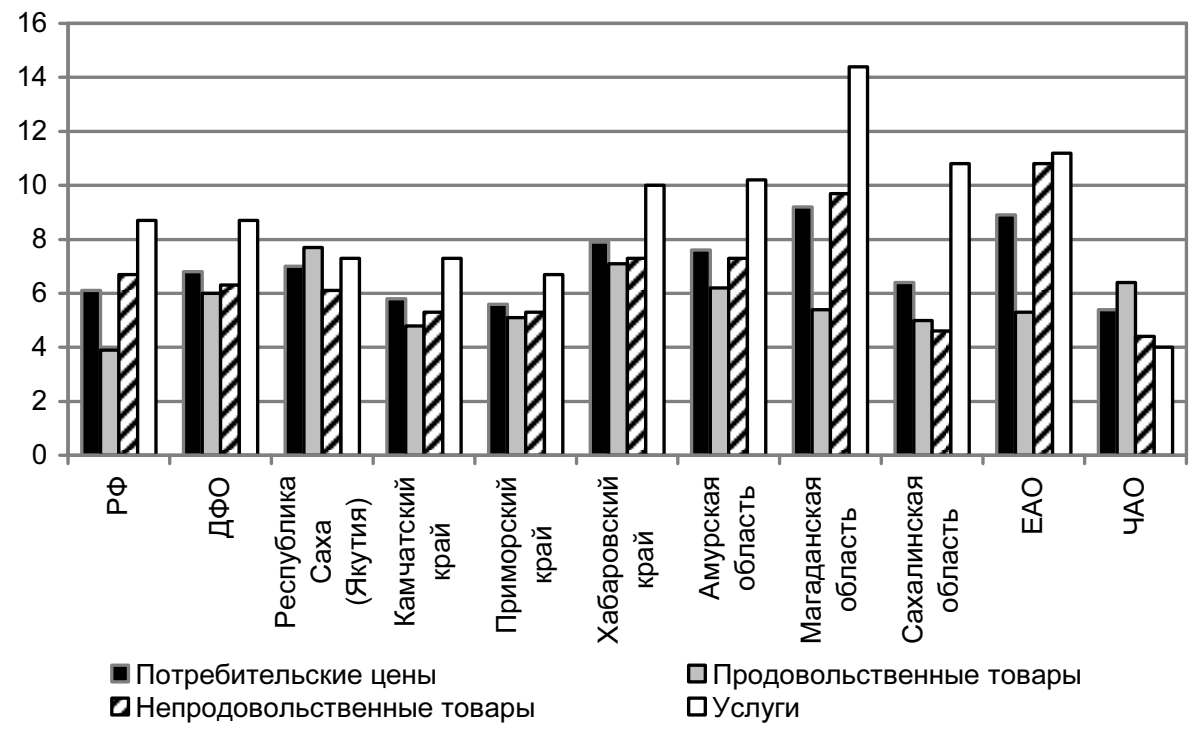

Puc. 3. Прирост потребительских цен, декабрь 2011 г. в \% к декабрю 2010 г. 
В минувшем году диспропорции в темпах роста между ценами производителей промышленной продукции и потребительскими ценами еще более усилились. Если в 2010 г. превышение роста цен производителей промышленной продукции над потребительскими ценами в целом по ДФО составляло 2,7 п. П., то в 2011 г. - 10,9 п. п. Наибольший рост цен производителей промышленных товаров отмечен в Сахалинской области $(132,8 \%)$ и ЧАО (124,9\%) (табл. 10). Как и в минувшем году, ценовая политика в промышленности обусловлена изменением цен в добывающем секторе экономики, который в большей степени реагирует на изменения на мировых рынках нефти и нефтепродуктов, драгоценных металлов. Также высокий рост цен наблюдался в секторе инвестиционных товаров, особенно для нужд строительства.

Таблица 10

Индексы цен производителей, декабрь 2011 г. к декабрю 2010 г., \%

\begin{tabular}{l|c|c|c|c}
\hline \multicolumn{1}{c|}{ Территория } & $\begin{array}{c}\text { Цены произ- } \\
\text { водителей про- } \\
\text { мышленных } \\
\text { товаров }\end{array}$ & $\begin{array}{c}\text { Цены на реали- } \\
\text { зованную сель- } \\
\text { хозпродукцию }\end{array}$ & $\begin{array}{c}\text { Цены про- } \\
\text { взодителей } \\
\text { строитель- } \\
\text { стве }\end{array}$ & $\begin{array}{c}\text { Тарифы } \\
\text { на грузо- } \\
\text { вые пере- } \\
\text { возки }\end{array}$ \\
\hline Российская Федерация & 112,0 & 94,9 & 109,3 & 108,4 \\
\hline ДФО & 117,7 & 106,1 & 106,3 & 108,3 \\
\hline $\begin{array}{l}\text { Республика Саха } \\
\text { Якутия) }\end{array}$ & 107,9 & 113,9 & 107,0 & 103,8 \\
\hline Камчатский край & 106,5 & 94,1 & 102,0 & 89,5 \\
\hline Приморский край & 107,1 & 102,4 & 106,5 & 107,3 \\
\hline Хабаровский край & 110,9 & 105,1 & 106,2 & 108,7 \\
\hline Амурская область & 114,1 & 107,7 & 103,8 & 97,5 \\
\hline Магаданская область & 114,6 & 116,4 & 110,1 & 133,2 \\
\hline Сахалинская область & 132,8 & 98,6 & 106,2 & 104,3 \\
\hline ЕАО & 111,1 & 116,5 & 112,5 & 117,5 \\
\hline ЧАО & 124,9 & 98,6 & $\ldots$ & 109,4 \\
\hline
\end{tabular}

Источник: [17].

Цены на реализованную сельскохозяйственную продукцию в 2011 г. увеличились на $6,1 \%$ на фоне снижения среднероссийского показателя. Значительный рост (114-117\%) отмечен в Республике Саха (Якутия), Магаданской области и ЕАО. Существенное влияние на рост показателя оказывало повышение цены на зерновые и зернобобовые культуры, продукцию животноводства (яйцо куриное, крупный рогатый скот, молоко).

Прирост цен на строительно-монтажные работы составил 6,3\%, что является следствием роста инвестиционной активности. 
Индекс тарифов на грузовые перевозки увеличился на 8,3\%. Рост тарифов наблюдался на перевозку грузов автомобильным, авиационным, морским, железнодорожным видами транспорта.

По оценкам экспертов, в 2012 г. инфляционные ожидания будут выше заявленных (5-6\%) Министерством экономического развития. Обусловлено это тем, что переиндексацию тарифов на услуги ЖКХ предполагается проводить в 2 этапа, что приведет к отложенному повышению тарифов. В большей степени предполагается повышение тарифов на электроэнергию, рост которых составит 12-15\%. В результате это окажет значительное влияние на рост инфляции, которая может составить 8-9\%. Переиндексации также подвергнутся тарифы на теплоэнергию и газ, повышение которых составит 8-10\% ежегодно. В связи с этим увеличится стоимость железнодорожных грузовых и пассажирских перевозок [8].

\section{ПРОИЗВОДСТВО ТОВАРОВ И УСЛУГ}

\section{Промышленное производство}

Добыча полезных ископаемых. В добывающем секторе экономики ДФО доминирует добыча топливно-энергетических ресурсов (65\% в 2011 г.). Добыча нефти и газового конденсата на Дальнем Востоке в 2011 г. выросла на $14 \%$, природного газа - на 6\%. Лидирующие позиции по-прежнему занимает Сахалинская область (табл. 11). Данный субъект Федерации в последние годы демонстрирует незначительные темпы повышения добычи углеводородов, так как регион подошел к стадии пиковой загрузки мощностей по добыче. Динамику данного сектора экономики ДФО определяет главным образом Республика Саха (Якутия), удельный вес которой в структуре отрасли постоянно увеличивается. Добыча нефти в республике в 2011 г. выросла на 59,3\%, природного газа - на $9 \%$.

В 2011 г. также отмечался рост добычи цветных металлов на 9,5\% в целом по Дальнему Востоку. За счет роста добычи на 41,7\% лидирующие позиции в ДФО заняла Амурская область. В то же время сокращение добычи цветных металлов в Чукотском автономном округе почти на $10 \%$ снизило удельный вес региона с 23,9\% в 2010 г. до 19,6\% в 2011 г. (см. табл. 11). Темпами выше, чем по Дальнему Востоку в среднем, росла добыча цветных металлов в Магаданской области, в то время как Республика Саха (Якутия) и Хабаровской край в 2011 г. демонстрировали темпы роста ниже, чем в среднем по ДФО. Тем не менее это лишь незначительно повлияло на удельный вес трех указанных территорий в структуре добычи цветных металлов. Более чем в 5 раз выросли объемы добычи в Еврейской автономной области, однако на данный регион приходится менее 0,5\% добычи Дальнего Востока. 
Добыча полезных ископаемых в Дальневосточном федеральном округе, \%

\begin{tabular}{|c|c|c|c|c|c|c|}
\hline \multirow{3}{*}{ Территория } & \multicolumn{3}{|c|}{$\begin{array}{c}\text { Топливно-энергетические } \\
\text { ресурсы }\end{array}$} & \multicolumn{3}{|c|}{ Руды цветных металлов } \\
\hline & \multicolumn{2}{|c|}{ структура } & \multirow{2}{*}{$\begin{array}{c}\text { темп роста, } \\
2011 / 2010 \\
\end{array}$} & \multicolumn{2}{|c|}{ структура } & \multirow{2}{*}{$\begin{array}{c}\text { темп роста, } \\
\text { 2011/2010 }\end{array}$} \\
\hline & 2010 & 2011 & & 2010 & 2011 & \\
\hline ДФО & 100 & 100 & 107,9 & 100 & 100 & 109,5 \\
\hline Республика Саха (Якутия) & 100,8 & 18,7 & 135 & 16,8 & 15,46 & 14,95 \\
\hline Камчатский край & 80,4 & 0,12 & 346,9 & 3,78 & 2,77 & 0,04 \\
\hline Приморский край & 0,7 & 0,71 & 109,3 & 3,56 & 3,6 & 110,7 \\
\hline Хабаровский край & 0,44 & 0,5 & 122,8 & 13,32 & 12,76 & 104,9 \\
\hline Амурская область & 0,31 & 0,3 & 106,2 & 20,85 & 26,97 & 141,7 \\
\hline Магаданская область & 0,11 & 0,1 & 98,6 & 17,79 & 18,67 & 115 \\
\hline Сахалинская область & 83,27 & 79,4 & 102,9 & - & - & - \\
\hline EAO & 0 & 0 & - & 0,03 & 0,13 & 560 \\
\hline ЧАО & 0,19 & 0,16 & 94,4 & 23,87 & 19,63 & 90,1 \\
\hline
\end{tabular}

Источник: [13].

Лесной комплекс. В ДФО продолжается изменение структуры лесной промышленности в пользу производств с высокой добавленной стоимостью. Так, в 2011 г. рост производства необработанной древесины составил 2,5\%, тогда как продукция деревообработки увеличилась на 29\% (табл. 12). Однако объемы производства необработанной древесины значительно превосходят объемы деревообработки. В отчетном году было произведено 12 млн м ${ }^{3}$ необработанной древесины и только 1,7 млн м³ обработанных лесоматериалов.

Таблииа 12

Структура и динамика лесной и деревообрабатывающей промышленности ДФО, \%

\begin{tabular}{l|c|c|c|c}
\hline \multirow{2}{*}{ Территория } & \multicolumn{2}{|c|}{ Древесина необработанная } & \multicolumn{2}{c}{ Лесоматериалы обработанные } \\
\cline { 2 - 5 } & структура & $\begin{array}{c}\text { темп роста, } \\
2011 / 2010\end{array}$ & структура & $\begin{array}{c}\text { темп роста, } \\
2011 / 2010\end{array}$ \\
\hline ДФО & 100 & 102,5 & 100 & 128,9 \\
\hline Республика Саха (Якутия) & 5,9 & & 103,3 & 8,6 \\
\hline Камчатский край & 1,1 & 97,9 & 1,3 & 103,5 \\
\hline Приморский край & 33 & 100,8 & 25,6 & 128,6 \\
\hline Хабаровский край & 51,2 & 105,1 & 51,5 & 145,9 \\
\hline Амурская область & 6,6 & 93,2 & 6,9 & 118,3 \\
\hline Магаданская область & 0,2 & 100 & 0 & в 2,8 p. \\
\hline Сахалинская область & 1,7 & 104,1 & 3 & 83,6 \\
\hline ЕАО & 0,5 & 82,8 & 3 & 99,5 \\
\hline ЧАО & 0 & - & 0 & - \\
\hline
\end{tabular}

Источник: [13]. 
№ 22012

Половина лесной промышленности Дальнего Востока сосредоточена в Хабаровском крае. Если в 2010 г. доля производства необработанной древесины в Приморском и Хабаровском краях превышала 90\%, то в 2011 г. в Хабаровском крае доля лесопереработки составила 12,5\%. В Республике Саха (Якутия), Амурской и Сахалинской областях, Еврейской автономной области (21,5\% деревообрабатывающей промышленности ДФО) удельный вес лесопереработки также превышает 10\% (в Еврейской автономной области - 48,6\%).

Рыбохозяйственный комплекс. В 2011 г. рыбоперерабатывающая промышленность ДФО демонстрировала рост. Объем рыбопереработки составил 2105 тыс. т, что на 9,8\% выше уровня 2010 г. В Камчатском и Приморском краях, чей удельный вес в рыбопереработке Дальнего Востока составляет 31,7 и 30,9\% соответственно, темп роста в данном сегменте промышленности превысил 10\%. В Сахалинской области (удельный вес 21,8\%) рост объемов рыбопереработки составил 8\%. Объем экспорта рыбы и морепродуктов увеличился на 2,3\% (табл. 13) и составил 1188 тыс. т, или 1794 млн долл.

Таблица 13

Экспорт рыбы и морепродуктов в натуральном выражении, в \% к предыдущему году

\begin{tabular}{l|c|c|c|c}
\hline \multicolumn{1}{c|}{ Территория } & 2009 & 2010 & 2011 & Структура, 2011 \\
\hline ДФО & 102,2 & 123,9 & 102,3 & 100 \\
\hline Камчатский край & 90,2 & 117,9 & 84,6 & 21,1 \\
\hline Приморский край & 117,5 & 128,8 & 110,1 & 38,7 \\
\hline Хабаровский край & 96,9 & 133,4 & 89,6 & 8,6 \\
\hline Магаданская область & 77,5 & 133,7 & 120,6 & 4,5 \\
\hline Сахалинская область & 97,3 & 119,1 & 112 & 23,3 \\
\hline ЧАО & 195,4 & 117,7 & 3,8 & 106,7 \\
\hline
\end{tabular}

Источник: [13].

Обрабатывающая промышленность. Объем металлургического производства в ДФО в 2011 г. увеличился на 10\%. Основным дальневосточным субъектом РФ, специализирующимся на черной металлургии, является Хабаровский край $(62,5 \%$ всего металлургического производства ДФО в 2010 и 2011 гг.). Здесь отрасль демонстрирует постепенное преодоление кризисных последствий после существенного сокращения выпуска в 2009 г. на 51,2\%. В 2010 и 2011 гг. рост выпуска составил 23,8 и 10,1\% соответственно. 22\% выпуска черной металлургии ДФО в 2011 г. приходилось на Приморский край. Если в 2010 г. Республика Саха (Якутия) и Приморский край делили второе место в структуре металлургической промышленности Дальнего Востока (по 13,3\%), то в 2011 г. выпуск продукции черной металлургии в Республике Саха (Якутия) сократился на 59,9\%, а в Приморском крае вырос на 83,1\%. 
Производство строительных материалов в 2011 г. демонстрировало рост. Так, производство цемента возросло на 18\%, а сборных железобетонных конструкций - на 4,1\%. Если в 2010 г. в ДФО наблюдался значительный рост выпуска железобетонных строительных конструкций практически по всем субъектам РФ, то в 2011 г. в Приморском и Хабаровском краях (62\% в структуре выпуска) отмечалось снижение объемов производства на 2,3 и 2,4\% соответственно. Рост выпуска наблюдался в Республике Саха (Якутия) $(10,4 \%)$, Камчатском крае $(15,7 \%)$, Амурской области (35\%) и Еврейской автономной области (33,6\%). Указанные территории занимают в сумме $33,1 \%$ в структуре выпуска железобетонных конструкций по Дальнему Востоку.

На машиностроительном производстве специализируются два субъекта РФ Дальнего Востока - Приморский и Хабаровский края. Если до 2010 г. Хабаровский край лидировал по объемам выпуска машиностроительной продукции, то затем лидерство перешло к Приморскому краю.

Наибольший удельный вес в структуре машиностроения ${ }^{1}$ ДФО занимает производство транспортных средств (80\% в 2011 г.). Данный сектор экономики является единственным сегментом промышленности, чье производство базируется на высоких технологиях (авиастроение и автомобилестроение) и характеризуется высокой долей добавленной стоимости. До недавнего времени лидерство в этом виде деятельности также сохранял Хабаровский край. В 2011 г. Приморский край увеличил производство транспортных средств на 45,3\% по сравнению с 2010 г., в то время как Хабаровский край только на $17,3 \%$. В результате на Приморский край приходится более половины $(53 \%)$ дальневосточного выпуска транспортных средств (на Хабаровский край $40 \%)$. Производство машин и оборудования менее концентрировано в отдельных субъектах ДФО, хотя на Приморский и Хабаровский края приходится более половины выпуска (61\%). Следует отметить, что в данных регионах этот сегмент промышленности не демонстрирует признаки послекризисного восстановления. Так, в Приморском крае выпуск машин и оборудования сократился на 17\% по сравнению с 2010 г., в Хабаровском крае - на $38 \%$.

\section{Сельское хозяйство}

В 2011 г. в сельском хозяйстве ДФО сохраняются положительные тенденции развития. Объем валовой продукции сельского хозяйства составил 115,6 млрд руб., или 105,8\% (в сопоставимых ценах) к уровню 2010 г. Рост объема продукции сельского хозяйства отмечен практически по всем (кроме Республики Саха (Якутия) и Магаданской области) территориям округа.

1 Виды экономической деятельности: производство машин и оборудования; производство электрооборудования, электронного и оптического оборудования; производство транспортных средств. 
№ 22012

Наибольший вклад в формирование положительных темпов роста внесли Амурская область и Приморский край, совокупная доля которых в общем объеме продукции сельского хозяйства составляет почти 50\%. Рост производства в ЧАО $(144,6 \%)$ не мог оказать большого влияния на увеличение показателя в целом по ДФО, поскольку доля продукции сельского хозяйства ЧАО незначительна $(0,4 \%)$ (табл. 14).

Индексы производства продукции сельского хозяйства

Таблица 14 (в хозяйствах всех категорий), в \% к предыдущему году

\begin{tabular}{l|c|c|c|c}
\hline \multicolumn{1}{c|}{ Территория } & 2009 & 2010 & 2011 & Справочно, 2011/2008 \\
\hline Российская Федерация & 101,4 & 88,7 & 122,1 & 109,8 \\
\hline ДФО & 103,1 & 101,8 & 105,8 & 111,0 \\
\hline Республика Саха (Якутия) & 100,2 & 97,3 & 95,8 & 93,4 \\
\hline Камчатский край & 94,9 & 97,8 & 101,0 & 93,7 \\
\hline Приморский край & 109,2 & 103,9 & 109,7 & 124,5 \\
\hline Хабаровский край & 101,6 & 99,3 & 100,0 & 100,9 \\
\hline Амурская область & 112,0 & 103,0 & 117,3 & 135,3 \\
\hline Магаданская область & 104,1 & 100,2 & 90,8 & 94,7 \\
\hline Сахалинская область & 87,3 & 107,3 & 104,6 & 98,0 \\
\hline ЕАО & 92,2 & 109,0 & 103,6 & 104,1 \\
\hline ЧАО & 90,8 & 92,8 & 144,6 & 121,8 \\
\hline
\end{tabular}

Источники: [15; 17].

Положительная динамика развития отрасли обеспечена увеличением объемов продукции растениеводства, рост которой составил $110,6 \%$ относительно 2010 г. В минувшем году валовой сбор зерновых культур составил 703 тыс. т, что в 2 раза превысило низкий из-за погодно-климатических условий уровень 2010 г. и на 21\% - показатели 2009 г. (табл. 15). Отмечено сохранение на уровне 2010 г. производства картофеля и увеличение производства овощей.

Формирование положительных темпов роста в растениеводстве также связано с увеличением производства сои. Валовой сбор этой технической культуры составил 1,1 млн т, что на 35,9\% выше уровня 2010 г. (табл. 16). Основным производителем сои является Амурская область, на долю которой приходится около $75 \%$ произведенной продукции. Увеличение в области производства сои и повышение ее урожайности связано как с увеличением посевных площадей, так и с обновлением агротехники.

Сдерживающим фактором развития соеводства является существующая ныне практика таможенного регулирования, когда экспортные таможенные пошлины на сою сохраняются на уровне $20 \%$ от таможенной стоимости. Не- 
обходимо решение вопросов применения льготного тарифа на перевозку зерна и продукции мукомольно-крупяной промышленности, сои и соевого шрота начиная с нулевого километра, что позволит увеличить импортозамещение и обеспечить продовольственную безопасность региона [12].

Валовой сбор урожая в хозяйствах всех категорий в 2011 г.

Таблица 15

\begin{tabular}{l|c|c|c|c|c|c}
\hline \multirow{2}{*}{\multicolumn{1}{c}{ Территория }} & \multicolumn{2}{|c|}{$\begin{array}{c}\text { Зерновые (в весе } \\
\text { после доработки) }\end{array}$} & \multicolumn{2}{c|}{ Картофель } & \multicolumn{2}{c}{ Овощи } \\
\cline { 2 - 8 } & тыс. т & в \% к 2010 & тыс. т & в \% к 2010 & тыс. т & в \% к 2010 \\
\hline ДФО & 702,8 & в 2 р. & 1286,3 & 100,0 & 429,9 & 107,2 \\
\hline Республика Саха (Якутия) & 7,8 & 76,1 & 69,7 & 98,4 & 32,3 & 95,9 \\
\hline Камчатский край & 0,1 & 18,6 & 45,4 & 98,6 & 16,6 & 102,8 \\
\hline Приморский край & 230,5 & 159,3 & 379,8 & 105,6 & 182,3 & 113,2 \\
\hline Хабаровский край & 100,4 & 186,5 & 280,6 & 99,3 & 61,3 & 105,1 \\
\hline Амурская область & 338,2 & в 2,6 p. & 295,8 & 97,3 & 60,9 & 103,3 \\
\hline Магаданская область & - & - & 12,7 & 83,6 & 4,1 & 82,7 \\
\hline Сахалинская область & - & - & 96,5 & 106,4 & 36,6 & 108,6 \\
\hline ЕАО & 25,8 & в 4,3 р. & 105,8 & 90,2 & 35,7 & 104,1 \\
\hline ЧАО & - & - & 0,02 & 66,7 & 0,1 & 116,7 \\
\hline
\end{tabular}

Источник: [13].

Валовой сбор и урожайность сои (в хозяйствах всех категорий)

Таблица 16

\begin{tabular}{l|c|c|c|c}
\hline \multirow{2}{*}{ Территория } & \multicolumn{2}{|c|}{ Валовой сбор, тыс. т } & \multicolumn{2}{c}{ Урожайность, ц/га } \\
\cline { 2 - 5 } & 2010 & 2011 & 2010 & 2011 \\
\hline ДФО & 816,6 & 1109,5 & $\ldots$ & $\ldots$ \\
\hline Приморский край & 152,2 & 168,3 & 11,1 & 11,9 \\
\hline Хабаровский край & 14,7 & 14,4 & 10,0 & 11,6 \\
\hline Амурская область & 570,0 & 826,8 & 12,6 & 14,7 \\
\hline ЕАО & 79,7 & 100,0 & 12,2 & 13,7 \\
\hline
\end{tabular}

Источник: [13].

В животноводческом комплексе ДФО в 2011 г. отмечалось небольшое (на 0,2 п. п.) снижение производства продукции. На формирование отрицательной динамики оказало влияние сокращение поголовья коров $(99,6 \%$ к 2010 г.) и, как следствие, снижение производства молока (98,6\% к 2010 г.). Низкая продуктивность кур-несушек явилась причиной сокращения производства яйца (98,3\% к 2010 г.). Незначительный рост (101,7\% к 2010 г.) производства мяса (на убой в живом весе) не смог перекрыть падения в остальных секторах животноводческого комплекса (табл. 17). 
2012

Таблица 17

Производство продукции животноводства в хозяйствах всех категорий в 2011 г.

\begin{tabular}{l|c|c|c|c|c|c}
\hline \multirow{2}{*}{\multicolumn{1}{c}{ Территория }} & \multicolumn{2}{|c|}{$\begin{array}{c}\text { Скот и птица (на } \\
\text { убой в живом весе) }\end{array}$} & \multicolumn{2}{c|}{ Молоко } & \multicolumn{2}{c}{ Яйцо } \\
\cline { 2 - 8 } & тыс. т & в \% к 2010 & тыс. т & в \% к 2010 & млн штук & в \% к 2010 \\
\hline Российская Федерация & 10900,0 & 103,7 & 31700,0 & 99,7 & 41000,0 & 101,0 \\
\hline ДФО & 194,4 & 101,5 & 583,3 & 98,6 & 1167,1 & 98,3 \\
\hline $\begin{array}{l}\text { Республика Саха } \\
\text { (Якутия) }\end{array}$ & 39,0 & 91,7 & 185,6 & 96,9 & 123,0 & 100,6 \\
\hline Камчатский край & 3,5 & 94,4 & 16,4 & 103,3 & $\ldots$ & 95,2 \\
\hline Приморский край & 54,2 & 104,7 & 105,7 & 96,6 & 328,4 & 106,3 \\
\hline Хабаровский край & 31,8 & 99,7 & 50,4 & 96,2 & 263,9 & 88,3 \\
\hline Амурская область & 53,5 & 107,9 & 168,4 & 104,0 & 248,6 & 96,6 \\
\hline Магаданская область & 0,7 & 100,0 & 5,8 & 101,7 & 20,7 & 103,9 \\
\hline Сахалинская область & 4,2 & 104,4 & 26,1 & 93,0 & 110,1 & 101,5 \\
\hline ЕАО & 5,4 & 96,1 & 24,7 & 94,0 & 23,8 & 112,0 \\
\hline ЧАО & 2,1 & 169,0 & 0,1 & 100,0 & 3,5 & 122,0 \\
\hline
\end{tabular}

Источники: [13; 18].

Аграрная политика в регионах Дальнего Востока осуществляется в рамках принятой Правительством РФ Государственной программы развития сельского хозяйства и регулирования рынков сельскохозяйственной продукции, сырья и продовольствия на 2008-2012 гг. Несмотря на принимаемые меры, сохраняется негативное влияние факторов, сдерживающих развитие агропромышленного комплекса ДФО: высокие транспортные издержки на поставку ресурсов, дефицит инвестиций и оборотных средств, диспаритет цен за счет отставания роста цен на реализуемую сельскохозяйственную продукцию по сравнению с ценами на промышленные товары и продовольствие, отсутствие высококвалифицированных кадров и др. [14]. Решение этих проблем в будущем позволит агропромышленному комплексу региона обеспечить население основными продуктами питания и снизить зависимость от импорта продовольствия.

\section{Строительство}

В строительном комплексе ДФО в 2011 г. сохранялись положительные тенденции развития. Объем строительных работ превысил уровень минувшего года на $6,6 \%$ против 5,1\% в целом по России. В большинстве дальневосточных субъектов РФ (кроме Хабаровского, Камчатского краев и ЕАО) отмечен рост производства, но наиболее активно строительная деятельность осуществлялась в ЧАО (рост $187,0 \%$ ) и Сахалинской области (рост $136,1 \%$ ) (табл. 18). 
Строительный комплекс в 2011 г.

Таблица 18

\begin{tabular}{l|c|c|c|c}
\hline \multirow{2}{*}{ Территория } & \multicolumn{2}{|c}{$\begin{array}{c}\text { Объем работ, выполненных } \\
\text { по виду деятельности } \\
\text { «строительсто» }\end{array}$} & \multicolumn{2}{c}{ Ввод жилья } \\
\cline { 2 - 5 } & млрд руб. & в \% к 2010 & тыс. м² & в \% к 2010 \\
\hline Российская Федерация & 5061,8 & 105,1 & 62300 & 106,6 \\
\hline ДФО & 385,1 & 106,6 & 1898,2 & 115,2 \\
\hline Республика Саха (Якутия) & 58,6 & 112,5 & 315,6 & 104,2 \\
\hline Камчатский край & 14,9 & 80,7 & 68,7 & 118,9 \\
\hline Приморский край & 122,6 & 114,1 & 583,1 & 108,9 \\
\hline Хабаровский край & 55,9 & 74,1 & 382,5 & 121,4 \\
\hline Амурская область & 32,1 & 108,1 & 240,2 & 144,4 \\
\hline Магаданская область & 8,6 & 114,0 & 18,2 & 114,1 \\
\hline Сахалинская область & 78,8 & 136,1 & 234,7 & 116,3 \\
\hline ЕАО & 11,9 & 99,7 & 53,0 & 100,8 \\
\hline ЧАО & 2,2 & 187,0 & 2,2 & 8,1 раза \\
\hline
\end{tabular}

Источник: [17].

По объему выполненных подрядных работ абсолютное лидерство, как и в прошлом году, сохраняется за Приморским краем (32\%), что связано со строительством автомобильных дорог, мостовых переходов, коммунальной и энергетической инфраструктуры, гостиниц и других объектов в рамках подготовки г. Владивостока к проведению саммита АТЭС в 2012 г. В тройку лидеров также входят Сахалинская область и Республика Саха (Якутия), доля которых по данному показателю составляет 20,5 и $15,2 \%$ соответственно.

В 2011 г. в целом по ДФО прирост количества вводимого жилья составил $15,2 \%$, и Дальний Восток сохранил, как и в минувшем году, лидерство среди федеральных округов РФ. Значительный объем работ в жилищном строительстве выполнен в ЧАО (рост в 8,1 раза), Амурской области $(144,4 \%)$, Хабаровском и Камчатском краях (121,4 и 118,9\% соответственно).

Положительное воздействие на ситуацию с вводом жилья продолжают оказывать мероприятия, запущенные в 2010 г. в рамках Программы антикризисных мер: выполнение обязательств по обеспечению жильем ветеранов Великой Отечественной войны 1941-1945 гг, расселение из аварийного и ветхого жилья, переселение с северных территорий, поддержка молодых семей. Определенный вклад в увеличение объемов жилищного строительства вносит продолжающееся улучшение условий ипотечного жилищного кредитования. 
№ 22012

\section{Транспорт}

В 2011 г. в транспортном комплексе ДФО сохраняется уверенный рост. Объем перевозки грузов всеми видами транспорта составил 241 млн т (рост $109,4 \%)$ и сравнялся с уровнем предкризисного 2008 г. Увеличение объемов перевозок грузов отмечается практически по всем видам транспорта (кроме морского), но наибольший объем перевезен внутренним водным $(123,9 \%)$, воздушным $(116,6 \%)$ и автомобильным $(111,7 \%)$ транспортом.

Грузооборот транспортного комплекса ДФО в 2011 г. составил 261 млрд т-км (105,0\%). Как и в минувшем году, увеличение объемов грузооборота связано с ростом объемов экспортных грузов, транспортировкой транзитной нефти, поставками необходимых строительных материалов для возведения объектов саммита АТЭС в г. Владивостоке.

Увеличение грузооборота в основном связано с железнодорожным транспортом, на долю которого приходится 86\% общего объема (рис. 4). Грузооборот железнодорожного транспорта увеличился на 6,9\% и составил 224,5 млрд т-км. Отмечен рост грузооборота на внутреннем водном $(112,4 \%)$, воздушном $(114,2 \%)$ и автомобильном (100,5\%) транспорте.

В 2011 г. объем пассажирооборота составил 18,7 млн пасс.-Км и остался практически на уровне 2010 г. (рост 100,1\%). В том числе на железнодорожном транспорте - 99,8\%, на внутреннем водном - 95,1, воздушном - 102,2, морском - 96,3, автомобильном - 97, $1 \%$.

Грузооборот

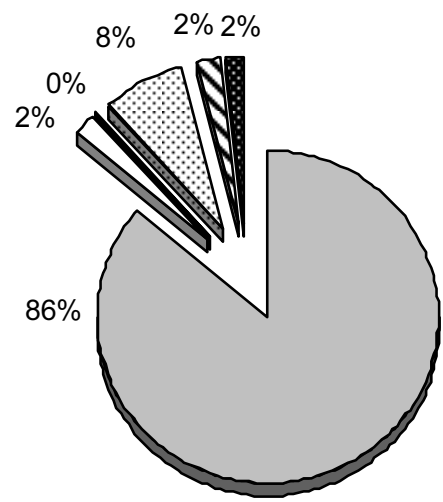

口Железнодорожный

口 Внутренний водный

- Воздушный

๑ Морской

ه Автомобильный

. Трубопроводный
Пассажирооборот

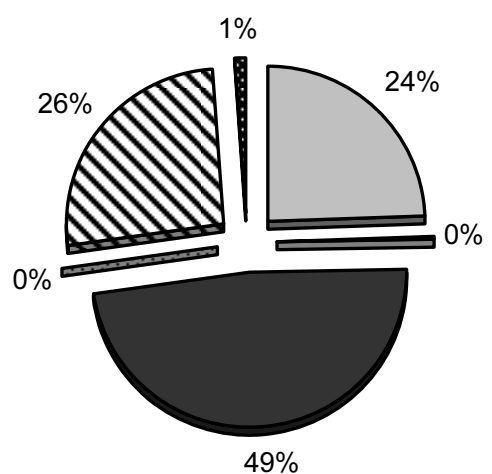

口Железнодорожный

口Внутренний водный

口Воздушный

๑орской

बАвтомобильный

ВГродской электротранспорт

Puc. 4. Структура грузо- и пассажирооборота транспорта ДФО в 2011 г. 
Рост пассажирооборота на воздушном транспорте связан с сохранением для жителей Дальнего Востока программы субсидирования авиаперевозок, а также гибкой тарифной политикой, проводимой авиакомпаниями.

В 2011 г. грузооборот портов Дальнего Востока увеличился до 125,3 млн т (рост 106,7\%). Из общего объема 70,9 млн т составили сухогрузы (рост $110,9 \%$ ), наливные грузы - 54,4 млн т (рост 101,6\%). Увеличили грузооборот порты Восточный, включая терминал в Козьмино (на 7,6\%, до 38,4 млн т), Ванино (на 10,2\%, до 19,1 млн т), Пригородное (на 1,4\%, до 16,3 млн т), Владивосток (на 5,8\%, до 11,8 млн т), Де-Кастри (на 9,3\%, до 8,1 млн т) и Посьет (на 14,4\%, до 5,3 млн т). Грузооборот порта Находка сократился на 2,5\% и составил 15,0 млн т [4].

\section{СОЦИАЛЬНАЯ СФЕРА}

\section{Доходы населения}

В 2011 г. среднедушевые номинальные денежные доходы населения в среднем по ДФО составили 22,9 тыс. руб. и увеличились по сравнению с минувшим годом на $10,1 \%$. Сохраняющийся опережающий рост доходов населения по сравнению с ростом потребительских цен обеспечил увеличение реальных доходов населения практически во всех (кроме Сахалинской области) дальневосточных субъектах РФ не только в минувшем году, но и в течение 2009-2010 гг. (табл. 19).

Таблииа 19

Динамика реальных денежных доходов населения, в \% к предыдущему году

\begin{tabular}{l|c|c|c}
\hline \multicolumn{1}{c|}{ Территория } & 2009 & 2010 & 2011 \\
\hline Российская Федерация & 101,8 & 104,7 & 101,1 \\
\hline ДФО & 104,0 & 103,5 & $\ldots$ \\
\hline Республика Саха (Якутия) & 101,7 & 102,7 & 103,7 \\
\hline Камчатский край & 103,9 & 102,3 & 104,8 \\
\hline Приморский край & 106,5 & 105,9 & 101,9 \\
\hline Хабаровский край & 108,4 & 105,3 & 102,5 \\
\hline Амурская область & 94,5 & 98,4 & 117,8 \\
\hline Магаданская область & 102,5 & 102,5 & 100,2 \\
\hline Сахалинская область & 99,4 & 98,9 & 95,9 \\
\hline ЕАО & 104,7 & 102,7 & 100,1 \\
\hline ЧАО & 91,9 & 104,0 & 108,9 \\
\hline
\end{tabular}

Источники: $[1 ; 13 ; 15]$.

В сфере оплаты труда сохранялась динамика роста номинальной и реальной заработной платы. В среднем по округу среднемесячная начисленная за- 
работная плата в 2011 г. составила 28,3 тыс. руб. и увеличилась по сравнению с прошлым годом на 9,7\%. В 2011 г. сохранялась высокая дифференциация заработной платы между различными сферами экономической деятельности. Максимальный размер среднемесячной заработной платы, как и в прошлом году, сохраняется в финансовом секторе ЧАО (123,7 тыс. руб.), минимальный - в сельском хозяйстве и торговле ЕАО, рыболовстве и сельском хозяйстве Якутии (9,1-11,1 тыс. руб.). Не произошло существенных изменений и в структуре высокодоходных сфер деятельности. По-прежнему лидерами по уровню заработной платы оставались добывающий и финансовый сектора экономики, в которых оплата труда значительно (в 1,8-1,9 раза) превышала среднемесячную заработную плату в целом по экономике ДФО.

Несмотря на то, что в 2011 г. Правительством РФ проводились мероприятия по повышению минимальных государственных гарантий по оплате труда, индексации фондов оплаты труда работникам федеральных государственных учреждений, увеличению размера оплаты труда наименее оплачиваемым работникам федеральных музеев, библиотек и архивов, модернизации региональной системы общего образования и здравоохранения, сохраняется значительный разрыв в оплате труда в бюджетных отраслях и отраслях реального сектора экономики. Так, уровень среднемесячной начисленной заработной платы работников здравоохранения и предоставления социальных услуг за январь - ноябрь 2011 г. к ее уровню в добывающих отраслях составлял 40,5\%, в обрабатывающих производствах - 86,9\% (в январе - ноябре 2010 г. соответственно 43,8 и 89,3\%). Уровень среднемесячной начисленной заработной платы работников образования составил 35,0\% к уровню в добывающих отраслях и 75,1\% - в обрабатывающих производствах (в январе - ноябре 2010 г. соответственно 37,7 и 76,7\%).

Рост реальной заработной платы (с учетом изменения цен) по сравнению с 2010 г. составил 105,1\%, что на 0,9 п. п. выше аналогичного среднероссийского показателя. Реальная заработная плата сохранила положительную динамику роста во всех регионах Дальнего Востока России.

В течение года наблюдалась ситуация невыплаты заработной платы. Суммарная задолженность по заработной плате на 1 января 2012 г. составила 73 млн руб. и за предыдущий месяц сократилась на 22,2\%. Рост задолженности по заработной плате отмечался в Приморском крае $(117,5 \%)$ и Магаданской области $(101,6 \%)$, в остальных регионах Дальнего Востока снижение составляло 27-46\%. В общем объеме просроченной задолженности по заработной плате почти $38 \%$ приходилось на обрабатывающие производства, $24 \%$ - на транспорт, $12 \%$ - сельское хозяйство, $10 \%$ - строительство. Основная часть суммарной задолженности по заработной плате $(96,4 \%)$ связана с отсутствием у предприятий и организаций собственных средств. 


\section{Демографическая ситуация}

На 1 января 2012 г. численность постоянного населения ДФО составляла 6265,8 тыс. человек и по сравнению с началом 2011 г. уменьшилась на 19,1 тыс. человек, или на $0,3 \%$. В среднем за год, по оценке Росстата, с учетом итогов Всероссийской переписи населения 2010 г., численность постоянного населения ДФО насчитывала 6275,4 тыс. человек. Естественная убыль населения в январе - ноябре 2011 г. составила 1468 человек и сократилась по сравнению с соответствующим периодом 2010 г. на 57\%. Естественный прирост населения традиционно сохраняется в северных регионах ДФО (Республика Саха (Якутия), Камчатский край, ЧАО), где существенное воздействие на воспроизводство населения оказывает влияние традиций на институт семьи. Надо отметить, что в остальных регионах ДФО хотя и сохраняется абсолютная убыль населения, но темп снижения заметно ниже уровня 2010 г. (табл. 20).

В 2011 г. общий коэффициент рождаемости (число родившихся на 1000 человек населения), по предварительным данным, составил 13,2 и сохранился на уровне 2011 г.

Таблица 20

Динамика общих коэффициентов рождаемости, смертности и естественного прироста (убыли) населения

\begin{tabular}{l|c|c|c|c|c|c}
\hline \multirow{2}{*}{ Территория } & \multicolumn{2}{|c|}{$\begin{array}{c}\text { Коэффициент } \\
\text { рождаемости }\end{array}$} & \multicolumn{2}{c|}{$\begin{array}{c}\text { Коэффициент } \\
\text { смертности }\end{array}$} & \multicolumn{2}{|c}{$\begin{array}{c}\text { Коэффициент } \\
\text { естественного прироста } \\
\end{array}$} \\
\cline { 2 - 8 } & 2010 & 2011 & 2010 & 2011 & 2010 & 2011 \\
\hline Российская Федерация & 12,5 & 12,6 & 14,2 & 13,5 & $-1,7$ & $-0,9$ \\
\hline ДФО & 13,2 & 13,2 & 13,8 & 13,4 & $-0,6$ & $-0,2$ \\
\hline Республика Саха (Якутия) & 16,8 & 17,1 & 9,8 & 9,3 & $+7,0$ & $+7,8$ \\
\hline Камчатский край & 12,1 & 12,4 & 12,6 & 12,0 & $-0,5$ & $+0,4$ \\
\hline Приморский край & 11,8 & 11,9 & 14,3 & 14,1 & $-2,5$ & $-2,2$ \\
\hline Хабаровский край & 12,9 & 12,9 & 14,6 & 14,6 & $-1,7$ & $-1,7$ \\
\hline Амурская область & 13,8 & 13,5 & 15,3 & 14,7 & $-1,5$ & $-1,2$ \\
\hline Магаданская область & 11,5 & 11,5 & 13,0 & 12,9 & $-1,5$ & $-1,4$ \\
\hline Сахалинская область & 12,1 & 11,8 & 14,9 & 14,1 & $-2,8$ & $-2,3$ \\
\hline ЕАО & 13,6 & 14,1 & 15,5 & 15,3 & $-1,9$ & $-1,2$ \\
\hline ЧАО & 14,7 & 13,7 & 13,8 & 11,1 & $+0,9$ & $+2,6$ \\
\hline
\end{tabular}

Источники: [15; 17].

Принимаемые на федеральном уровне меры по внедрению здорового образа жизни, профилактике профессиональных заболеваний, сокращению рабочих мест с вредными и опасными условиями труда [11] позволили снизить смертность населения. Общий коэффициент смертности населения (число 
№ 22012

умерших на 1000 человек населения) в 2011 г. составил 13,4 против 13,8 в 2010 г. Дальний Восток постепенно теряет свое преимущество в более низких показателях смертности населения относительно среднероссийского уровня, обусловленное более молодой возрастной структурой населения. Если в 2010 г. коэффициент смертности по ДФО был ниже среднероссийского показателя на 0,4 п. п., то в 2011 г. - лишь на 0,1 п. п.

За январь - ноябрь 2011 г. наблюдается снижение миграционного оттока населения. Сальдо миграции в 2011 г. в целом по ДФО хотя и было отрицательным (-17 212 человек $\left.{ }^{1}\right)$, но по сравнению с аналогичным периодом прошлого года сократилось на 7,4 тыс. человек. Если в 2010 г. на 10 человек, прибывших в ДФО, приходилось 13 человек, покидающих регион, то в 2011 г. это соотношение составляет 10:11. Сохраняется высокий отток населения из Республики Саха (Якутия) и Амурской области. На фоне общего миграционного оттока в трех регионах округа (Приморский и Хабаровский края, ЧАО) отмечен миграционный прирост (табл. 21).

Таблица 21

Общие итоги миграции населения по территориям ДФО (январь - ноябрь), чел.

\begin{tabular}{l|c|c|c|c|c|c}
\hline \multirow{2}{*}{ Территория } & \multicolumn{2}{c|}{ Число прибывших } & \multicolumn{2}{c|}{ Число выбывших } & \multicolumn{2}{c}{ Сальдо миграции } \\
\cline { 2 - 8 } & 2010 & 2011 & 2010 & 2011 & 2010 & 2011 \\
\hline ДФО & 169562 & 86671 & 186774 & 111274 & -17212 & -24603 \\
\hline Республика Саха (Якутия) & 23671 & 13379 & 33135 & 19858 & -9464 & -6479 \\
\hline Камчатский край & 7322 & 6071 & 9035 & 6442 & -1713 & -371 \\
\hline Приморский край & 54406 & 22490 & 52850 & 28802 & 1556 & -6312 \\
\hline Хабаровский край & 35450 & 17972 & 34457 & 20178 & 993 & -2026 \\
\hline Амурская область & 21017 & 14012 & 26593 & 17338 & -5576 & -3326 \\
\hline Магаданская область & 5220 & 2678 & 6944 & 4425 & -1724 & -1747 \\
\hline Сахалинская область & 15134 & 6060 & 15445 & 8906 & -311 & -2846 \\
\hline ЕАО & 4118 & 3209 & 5575 & 3752 & -1457 & -543 \\
\hline ЧАО & 3224 & 800 & 2740 & 1573 & 484 & -773 \\
\hline
\end{tabular}

Источник: [13].

В последнее время одним из объяснений желания покинуть место проживания является не ухудшение, а существенное улучшение благосостояния населения. Повышение уровня жизни привело к росту образованного и мобильного класса людей, которые чувствуют себя конкурентоспособными не только на российском, но и на мировом рынке труда и капитала. Они востребованы в наиболее развитых сферах деятельности и в состоянии легко перемещаться в любых направлениях [9]. Поэтому политика стабилизации населенческого потенциала в ДФО должна учитывать эти новые обстоятельства.

\footnotetext{
1 Январь - ноябрь 2011 г.
} 


\section{Рынок труда}

Оживление в экономике привело к увеличению спроса на рабочую силу. В 2011 г. численность безработных, определяемых по методологии МОТ, на основании обследования населения по проблемам занятости составила в ДФО 263,7 тыс. человек и сократилась по сравнению с 2010 г. на 14\%.

Число вакантных рабочих мест в органах службы занятости населения на конец декабря 2011 г. составляла 99,5 тыс. человек, или 105,1\%, к декабрю 2010 г. Наибольшую потребность в кадрах испытывают предприятия Приморского края (49,5 тыс. человек), Хабаровского края (15,3 тыс. человек), Республики Саха (Якутия) и Амурской области (8,7 и 8,6 тыс. человек соответственно).

Коэффициент напряженности на рынке труда в расчете на 100 заявленных вакансий в конце 2011 г. в целом по ДФО составил 81,6 человека и снизился на 20,5\%. Высока напряженность на рынке труда в Амурской области, где на одну вакансию претендует 1,6 человека, в ЧАО (1,5 человека), в Хабаровском крае (1,3 человека).

В минувшем году увеличилось среднее время поиска работы. Если в 2010 г. максимальное время, которое человек тратил на поиск удовлетворяющей его работы, составляло 8 месяцев, то в 2011 г. - 9,7 месяца. В минувшем году увеличилось число безработных, занимавшихся поиском работы 12 месяцев и более. Если в 2010 г. в ситуации застойной безработицы в целом по ДФО находилось 28,6\% безработных, то в 2011 г. - 34,2\% (табл. 22).

Численность безработных в 2011 г.

Таблица 22 (по данным обследований населения по проблемам занятости)

\begin{tabular}{l|c|c|c|c}
\hline \multicolumn{1}{|c|}{ Территория } & $\begin{array}{c}\text { Безра- } \\
\text { ботные, } \\
\text { тыс. чел. }\end{array}$ & $\begin{array}{c}2011 \\
\text { в \% к } \\
2010\end{array}$ & $\begin{array}{c}\text { Среднее время } \\
\text { поиска работы } \\
\text { безработными, } \\
\text { месяцев }\end{array}$ & $\begin{array}{c}\text { Доля в общей числен- } \\
\text { ности безработных, } \\
\text { ищущих работу } \\
\text { месяцев и более, \% }\end{array}$ \\
\hline ДФО & 263,7 & 85,9 & 8,0 & 34,2 \\
\hline Республика Саха (Якутия) & 43,2 & 99,5 & 7,9 & 36,2 \\
\hline Камчатский край & 12,8 & 88,2 & 6,3 & 18,9 \\
\hline Приморский край & 87,4 & 83,4 & 8,0 & 32,8 \\
\hline Хабаровский край & 53,0 & 75,4 & 8,0 & 34,9 \\
\hline Амурская область & 28,6 & 92,7 & 7,8 & 47,6 \\
\hline Магаданская область & 4,6 & 77,3 & 9,6 & 35,2 \\
\hline Сахалинская область & 24,2 & 88,5 & 8,0 & 38,4 \\
\hline ЕАО & 8,2 & 96,1 & 9,7 & 35,2 \\
\hline ЧАО & 1,7 & 132,6 & 7,8 & \\
\hline
\end{tabular}

Источник: [17]. 
№ 22012

В 2011 г. из федерального бюджета было выделено около 18 млрд руб. на предоставление субсидий бюджетам субъектов РФ на реализацию соответствующих региональных программ по снижению напряженности на рынке труда. В минувшем году дополнительно было предусмотрено софинансирование таких мероприятий, как переобучение женщин, работающих во вредных условиях; переобучение женщин, находящихся в отпуске по уходу за детьми до трех лет; переподготовка врачей в соответствии с программами модернизации здравоохранения субъектов Российской Федерации на 20112012 гг. [10].

\section{ВНЕШНЕЭКОНОМИЧЕСКОЕ СОТРУДНИЧЕСТВО}

\section{Иностранные инвестиции}

В 2011 г. на Дальнем Востоке России был отмечен существенный рост объемов привлечения иностранных инвестиций, уровень которых составил 9909,7 млн долл. США, или 135,5\% к объему 2010 г. $^{1}$ (рис. 5).

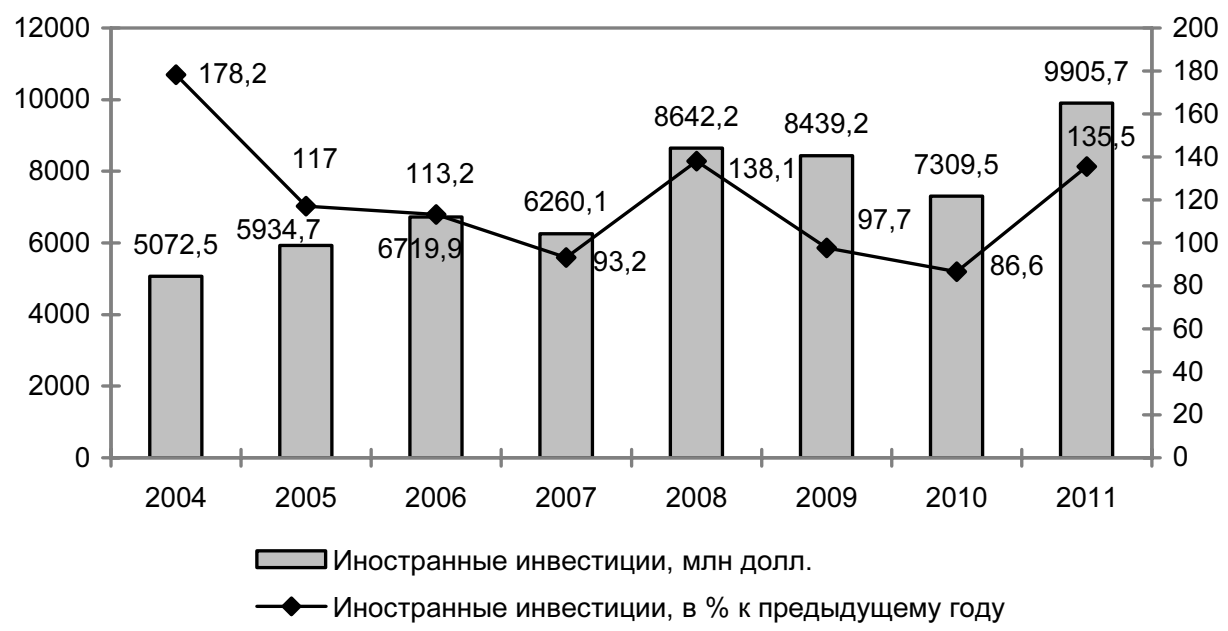

Puc. 5. Динамика поступления иностранных инвестиций на Дальний Восток России в 2004-2011 гг.

Структура иностранных инвестиций на Дальнем Востоке по видам их поступления в 2011 г. по сравнению с 2010 г. несколько изменилась (табл. 23).

\footnotetext{
${ }^{1}$ Объем иностранных инвестиций приведен с учетом рублевых поступлений, пересчитанных в доллары США. Все данные по иностранным инвестициям для субъектов Дальневосточного федерального округа (ДФО) были получены из Центральной базы статистических данных Федеральной службы государственной статистики.
} 
В целом для ДФО в структуре иностранных инвестиций наибольший удельный вес $(67,78 \%)$ занимают прочие инвестиции, осуществляемые на возвратной основе (торговые кредиты и кредиты международных финансовых организаций). На долю прямых инвестиций (в основном это взносы в уставный фонд, кредиты, прочие вложения) приходится 32,19\%, портфельных - 0,03\%.

Таблица 23

Распределение иностранных инвестиций на Дальнем Востоке по типу

\begin{tabular}{l|c|c|c|c}
\hline \multirow{2}{*}{\multicolumn{1}{c|}{ Тип инвестиций }} & \multicolumn{2}{c|}{2010} & \multicolumn{2}{c}{2011} \\
\cline { 2 - 5 } & тыс. долл. & $\%$ & тыс. долл. & $\%$ \\
\hline Всего & 7309521,07 & 100 & 9905678,39 & 100 \\
\hline Прямые инвестиции & 1170320,87 & 16,01 & 3188199,06 & 32,19 \\
\hline Портфельные инвестиции & 48247,4 & 0,66 & 3271,74 & 0,03 \\
\hline Прочие инвестиции & 6090952,8 & 83,33 & 6714207,59 & 67,78 \\
\hline
\end{tabular}

В 2011 г. было отмечено обвальное падение притока портфельных инвестиций до уровня в 3,271 млн долл., которые поступали только в Приморский и Хабаровский края, Республику Саха (Якутия) и Сахалинскую область (табл. 24).

Таблица 24

Структура иностранных инвестиций по дальневосточным субъектам РФ в 2011 г.

\begin{tabular}{|c|c|c|c|c|c|c|c|c|}
\hline \multirow{3}{*}{ Регион } & \multirow{2}{*}{\multicolumn{2}{|c|}{ Всего }} & \multicolumn{6}{|c|}{ В том числе } \\
\hline & & & \multicolumn{2}{|c|}{ прямые } & \multicolumn{2}{|c|}{ портфельные } & \multicolumn{2}{|c|}{ прочие } \\
\hline & тыс. долл. & $\%$ & тыс. долл. & $\%$ & $\begin{array}{l}\text { тыс. } \\
\text { долл. }\end{array}$ & $\%$ & тыс. долл. & $\%$ \\
\hline ДФО & 9905678,39 & 100 & 3188199,06 & 100 & 3271,74 & 100 & 6714207,59 & 100 \\
\hline $\begin{array}{l}\text { Республика Саха } \\
\text { (Якутия) }\end{array}$ & 1403543,91 & 14,17 & 23173,26 & 0,73 & 2422,3 & 74,04 & 1377948,35 & 20,52 \\
\hline Приморский край & 80841,26 & 0,82 & 53810,88 & 1,69 & 838,99 & 25,64 & 26191,39 & 0,39 \\
\hline Хабаровский край & 118446,02 & 1,20 & 92281,85 & 2,89 & 0,23 & 0,01 & 26163,94 & 0,39 \\
\hline Амурская область & 482954,38 & 4,88 & 425601,45 & 13,35 & - & - & 57352,93 & 0,85 \\
\hline Камчатский край & 34263,74 & 0,35 & 14631,74 & 0,46 & - & - & 19632 & 0,29 \\
\hline $\begin{array}{l}\text { Магаданская } \\
\text { область }\end{array}$ & 269501,31 & 2,72 & 269501,31 & 8,45 & - & - & - & - \\
\hline $\begin{array}{l}\text { Сахалинская } \\
\text { область }\end{array}$ & 7084776,31 & 71,52 & 2228358,16 & 69,89 & 10,22 & 0,31 & 4856407,93 & 72,33 \\
\hline EAO & 102085,55 & 1,03 & 21461,12 & 0,67 & - & - & 80624,42 & 1,2 \\
\hline ЧАО & 329265,92 & 3,32 & 59379,28 & 1,86 & - & - & 269886,64 & 4,02 \\
\hline
\end{tabular}


№ 22012

Падение объемов иностранных инвестиций в 2011 г. наблюдалось только в двух дальневосточных субъектах РФ: в Приморском крае - на 30\%, в Хабаровском крае - на 72\%. Объемы иностранных инвестиций существенно выросли в Магаданской области - в 90,6 раза, в ЧАО - в 13 раз, в ЕАО - в 6,3 раза, в Сахалинской области - на 42,6\%, в Амурской области - на 27\%. В других регионах наблюдался умеренный прирост. Как и в предыдущие годы, подавляющая часть как всех иностранных, так и прямых иностранных инвестиций (ПИИ), поступающих на Дальний Восток, направлялась в Сахалинскую область (71,52 и 69,89\% соответственно). Кроме того, прочие иностранные инвестиции (в основном осуществляемые на кредитной основе) в 2011 г. также были направлены в основном в Сахалинскую область (72,33\% от их общего объема), Республику Саха (Якутия) (22,52\%) и ЧАО (4,02\%).

Наиболее привлекательным для иностранного капитала видом экономической деятельности в ДФО является добыча полезных ископаемых (табл. 25).

Структура иностранных инвестиций на Дальнем Востоке

Таблица 25 по видам экономической деятельности

\begin{tabular}{l|c|c|c|c}
\hline \multirow{2}{*}{ Вид экономической деятельности } & \multicolumn{2}{|c|}{2010} & \multicolumn{2}{c}{2011} \\
\cline { 2 - 5 } & тыс. долл. & $\%$ & тыс. долл. & $\%$ \\
\hline Всего по экономике & 7309521,07 & 100 & 9905678,39 & 100 \\
\hline $\begin{array}{l}\text { Сельское хозяйство, охота и предоставление } \\
\text { услуг в этих областях }\end{array}$ & 40135,6 & 0,55 & 14808,15 & 0,15 \\
\hline Рыболовство, рыбоводство и лесное хозяйство & 15809,8 & 0,22 & 13592,64 & 0,14 \\
\hline Добыча полезных ископаемых & 6563212 & 89,79 & 9254982,07 & 93,43 \\
\hline Обрабатывающие производства & 342137,6 & 4,68 & 114021,09 & 1,15 \\
\hline Строительство & 19147,9 & 0,26 & 107308,14 & 1,08 \\
\hline $\begin{array}{l}\text { Оптовая и розничная торговля; ремонт авто- } \\
\text { транспортных средств, мотоциклов, бытовых } \\
\text { изделий и предметов личного пользования }\end{array}$ & 29663,6 & 0,41 & 24004,2 & 0,24 \\
\hline Гостиницы и рестораны & 918,7 & 0,01 & 281,09 & 0,00 \\
\hline Транспорт и связь & 75523,9 & 1,03 & 63003,87 & 0,64 \\
\hline Финансовая деятельность & 1330 & 0,02 & 615 & 0,01 \\
\hline $\begin{array}{l}\text { Операции с недвижимым имуществом, } \\
\text { аренда и предоставление услуг }\end{array}$ & 221640,97 & 3,03 & 311314,45 & 3,14 \\
\hline Образование & 0,4 & 0,00 & 898,4 & 0,01 \\
\hline $\begin{array}{l}\text { Производство и распределение электроэнер- } \\
\text { гии, газа и воды }\end{array}$ & 0,53 & 0,00 & 848,38 & 0,01 \\
\hline $\begin{array}{l}\text { Здравоохранение и предоставление } \\
\text { социальных услуг }\end{array}$ & - & - & 0,91 & 0,00 \\
\hline $\begin{array}{l}\text { Предоставление прочих коммунальных, } \\
\text { социальных и персональных услуг }\end{array}$ & - & - & - & - \\
\hline
\end{tabular}


В этот сектор было направлено 9,25 млрд долл. (93,43\% от всех поступлений). Это направление является основным для Магаданской области (практически весь объем инвестиций), Республики Саха (Якутия) (96,94\%), Сахалинской $(99,4 \%)$ и Амурской областей $(38,71 \%)$, EАО $(96,35 \%)$, ЧАО $(87,34 \%)$, Камчатского края $(36,48 \%)$.

Динамика привлечения иностранных инвестиций на российском Дальнем Востоке уже длительный период определяется реализацией проектов, связанных с добычей полезных ископаемых (минеральных ресурсов) на его территории. В сравнении с 2010 г. эта зависимость в отчетном году только усилилась. Доля иностранных инвестиций, направляемых в добычу полезных ископаемых, в 2011 г. повысилась до уровня в 93,43\% от всех вложений. При этом доля иностранных инвестиций, направленных в обрабатывающие производства, составила $1,15 \%$; строительство - 1,08; операции с недвижимым имуществом, арендой и предоставлением услуг - 3,14\%, из которых подавляющая часть была направлена на геологоразведочные, геофизические и геохимические работы в области изучения недр.

Сахалинская область, благодаря реализации на ее территории крупных проектов, связанных с разработкой нефтегазовых шельфовых месторождений, несколько увеличила свою долю в 2011 г. (до 71,52\% от всех иностранных инвестиций в ДФО) и продолжает сохранять лидирующие позиции по привлечению иностранных инвестиций среди дальневосточных субъектов РФ - объем иностранных инвестиций в Сахалинской области в 2011 г. вырос на 42\% по сравнению с 2010 г. и составил 7,085 млрд долл.

Таблииа 26

Иностранные инвестиции по лидирующим странам-инвесторам в 2010-2011 гг.

\begin{tabular}{l|c|c|c|c}
\hline \multirow{2}{*}{\multicolumn{1}{c|}{ Страна }} & \multicolumn{2}{c}{2010} & \multicolumn{2}{c}{2011} \\
\cline { 2 - 5 } & тыс. долл. & $\%$ & тыс. долл. & $\%$ \\
\hline ДФО & 7309521,07 & 100 & 9905678,39 & 100 \\
\hline Нидерланды & 2912806,1 & 39,85 & 4714377,6 & 47,59 \\
\hline Люксембург & 1300000 & 17,79 & 400000 & 4,04 \\
\hline Япония & 809517,3 & 11,07 & 907434,53 & 9,16 \\
\hline Багамские острова & 786296,8 & 10,76 & 891517,6 & 9,00 \\
\hline Кипр & 540149,2 & 7,39 & 1008842,18 & 10,18 \\
\hline Индия & 506980,5 & 6,94 & 574447,4 & 5,80 \\
\hline Великобритания & 185066,7 & 2,53 & 933930,57 & 9,43 \\
\hline Канада & 88150,87 & 1,21 & 75724,04 & 0,76 \\
\hline Китай & 45937,77 & 0,63 & 69901,34 & 0,71 \\
\hline Республика Корея & 42696,7 & 0,58 & 48978,74 & 0,49 \\
\hline
\end{tabular}


№ 22012

Вторым субъектом по уровню привлекательности для зарубежного капитала в 2011 г. (с объемом инвестиций в 1403,5 млн долл., или 14,17\% общих объемов в ДФО) стала Республика Саха (Якутия) - в 2011 г. поступление иностранных инвестиций в экономику республики выросло на $5 \%$.

Позиции лидирующих стран - инвесторов экономики Дальнего Востока в 2011 г. несколько изменились (табл. 26).

Основные страны-инвесторы, осуществляющие значительные инвестиционные вложения в ДФО в 2011 г.: Нидерланды - 4714,4 млн долл., Кипр 1009 млн долл., Великобритания - 934 млн долл., Япония - 907,4 млн долл., Багамские острова - 891,6 млн долл., Индия - 574,4 млн долл.

\section{Внешняя торговля}

Развитие внешней торговли Дальнего Востока в 2011 г. происходило на фоне заметного усиления позиций рубля по отношению к основным иностранным валютам (индекс реального эффективного курса рубля по сравнению с аналогичным периодом 2010 г. составил 4,7\%) [7], роста реальных денежных доходов населения $(108,1 \%)$ и реальной начисленной заработной платы $(105,1 \%)$ [6]. Наряду с этим в 2011 г. наметились положительные сдвиги в динамике внешнего спроса на рынках сопредельных стран и соответственно рост цен на традиционную продукцию регионального экспорта. Уже в первом квартале 2011 г. произошло восстановление уровня контрактных цен на лесотовары, рыбопродукцию, топливно-энергетические ресурсы, металлы.

Наличие вышеуказанных факторов позитивно отразилось на динамике внешней торговли региона. Внешнеторговый оборот ДФО с зарубежными странами в 2011 г. составил 34 млрд долл. [5], превысив докризисный уровень почти на 10 млрд долл. При этом активное сальдо торгового баланса региона сформировалось в размере 15,6 млрд долл., что на 43\% выше уровня 2010 г. (puc. 6).

Высокие темпы роста в 2011 г. были характерны для дальневосточного экспорта, стоимостный объем которого достиг наибольшей с начала 90-х гг. прошлого столетия величины - 24,8 млрд долл. Рост объемов экспорта в 2011 г. по сравнению с 2010 г. обеспечивался, главным образом, за счет продукции топливно-энергетического (с 11,8 до 16 млрд долл.) и алмазного (с 2,6 до 3,6 млрд долл.) комплексов региона. Приросты физических и стоимостных объемов, хотя и не столь значительные, были характерны также для прочих наиболее значимых позиций дальневосточного экспорта.

В товарной структуре экспорта ДФО в 2011 г. традиционно доминировала продукция сырьевых отраслей региона: нефте- и газодобывающей, горнодобывающей, рыбной, лесной. 


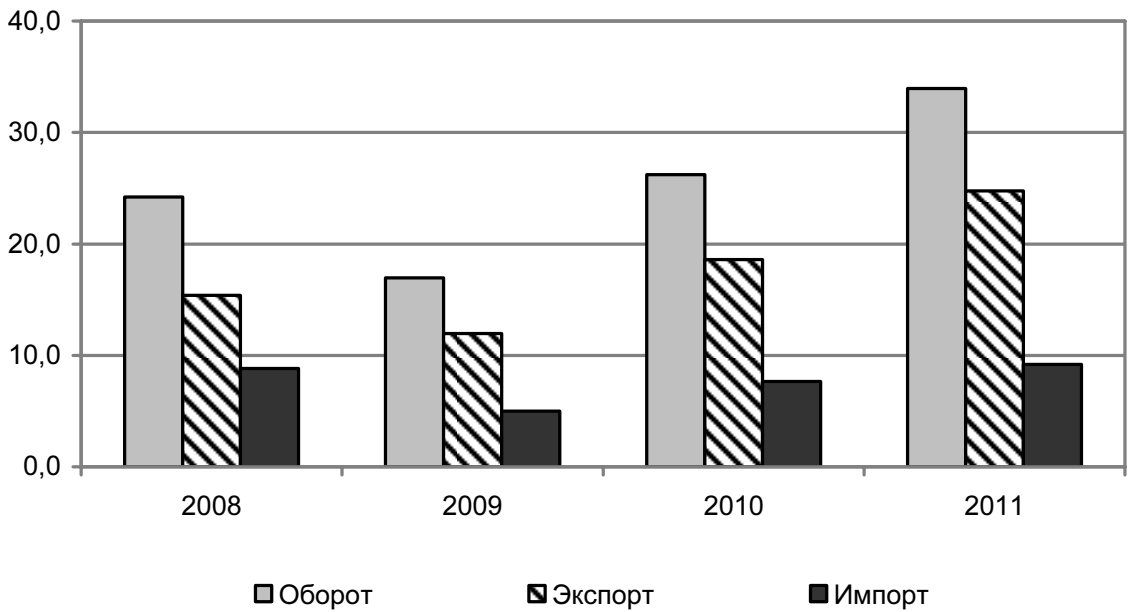

Puc. 6. Динамика внешней торговли Дальнего Востока России, млрд долл.

Наиболее высокий удельный вес в товарной структуре экспорта занимала продукция топливно-энергетического комплекса: нефть сырая, СПГ, уголь и нефтепродукты. Совокупная доля этих товаров в региональном экспорте составила $64,4 \%$.

Таблица 27

Товарная структура экспорта Дальнего Востока*

\begin{tabular}{l|c|c|c|c}
\hline \multirow{2}{*}{ Товарная группа } & \multicolumn{2}{c|}{2010} & \multicolumn{2}{c}{2011} \\
\cline { 2 - 5 } & млн долл. & $\%$ & млн долл. & $\%$ \\
\hline Экспорт, всего & 18579,0 & 100,0 & 24775,0 & 100,0 \\
\hline Машины, оборудование, транспортные средства & 315,3 & 1,7 & 598,3 & 2,4 \\
\hline Топливо, минеральное сырье, металлы & 12512,4 & 67,3 & 17124,4 & 69,1 \\
\hline продукция ТЭК & 11847,6 & 63,8 & 15965,6 & 64,4 \\
\hline металлы и изделия из них & 498,1 & 2,7 & 624,2 & 2,5 \\
\hline Химические товары & 50,5 & 0,3 & 148,1 & 0,6 \\
\hline Сырье и продукты его переработки & 1053,9 & 5,7 & 1155,0 & 4,7 \\
\hline лесотовары & 1052,9 & 5,7 & 1154,4 & 4,7 \\
\hline Пищевкусовые товары & 1980,3 & 10,7 & 2116,9 & 8,5 \\
\hline рыбопродукция & 1902,3 & 10,2 & 2050,3 & 8,3 \\
\hline Промышленные товары народного потребления & 0,9 & 0,0 & 1,2 & 0,0 \\
\hline Прочие & 2665,7 & 14,3 & 3631,1 & 14,7 \\
\hline
\end{tabular}

Примечание. * Без учета экспорта услуг, поставок бункерного топлива.

Источник: составлено по: [5]. 
№ 22012

Устойчивую нишу в дальневосточном экспорте продолжали занимать драгоценные металлы и продукция алмазного комплекса (14\%), а также продукция таких отраслей, как рыбная $(8,3 \%)$ и лесная $(4,7 \%)$.

В экспортных поставках продукции рыбной отрасли традиционно доминировали товары с низкой степенью обработки (94\%). Наибольший удельный вес в структуре экспорта рыбопродукции приходился на рыбу свежемороженую (91\%), в частности, минтай (61\%), сельдь (12\%), тихоокеанские лососи $(9,5 \%)$.

Аналогичная картина была характерна и для экспортных поставок лесной отрасли региона, в которых преобладала необработанная древесина. В то же время следует заметить, что начиная с 2008 г. в лесном экспорте имеет место устойчивая тенденция замещения сырья продукцией деревообработки. Так, если в 2008 г. экспорт необработанных лесоматериалов составлял 12,8 млн м², в 2009 г. - 8,2 млн м³ , в 2010 г. - 7,3 млн м³, то в 2011 г. экспорт снизился до 6,2 млн м³. Соответственно происходил рост объемов поставок обработанных лесоматериалов, объемы которых за период с 2008 по 2011 г. увеличились в 4,1 раза (с 325 тыс. т до 1319 тыс. т), что свидетельствует об эффективности мер, направленных на создание на российском Дальнем Востоке лесоперерабатывающей базы.

В отличие от экспорта, в структуре дальневосточного импорта преобладает продукция обрабатывающих отраслей, и прежде всего машиностроения. В 2011 г. вследствие роста физических и стоимостных объемов импорта машинотехнической продукции ее доля в структуре импорта составила свыше $46 \%$ (в 2010 г. $-38 \%$ ).

Рост объемов ввоза данной группы товаров обеспечивался за счет продукции производственно-технического назначения, используемой в отраслях экспортной специализации региона, а также транспортных средств. Согласно предварительным оценкам ДВТУ, в 2011 г. импорт легковых автомобилей по сравнению с 2009 г. вырос почти в три раза. Еще более резкий скачок импорта произошел на автобусы и грузовые автомобили [5].

Значительные изменения в 2011 г. произошли в структуре импорта товаров потребительского спроса. В частности, резко сократились (более чем на 300 млн долл.) объемы закупок промышленных товаров народного потребления, в результате чего их доля в структуре импорта снизилась с 29,3 до 20,9\% (табл. 28).

Главные рынки сбыта импортируемых из зарубежных стран товаров в 2011 г. формировали Приморский край, имеющий де-факто статус транзитной территории, Сахалинская область и Хабаровский край, совокупная доля которых в дальневосточном импорте составляла $87,3 \%$. 
Товарная структура импорта Дальнего Востока*

\begin{tabular}{l|c|c|c|c}
\hline \multirow{2}{*}{ Товарная группа } & \multicolumn{2}{|c}{2010} & \multicolumn{2}{c}{2011} \\
\cline { 2 - 5 } & млн долл. & $\%$ & млн долл. & $\%$ \\
\hline Импорт, всего & 7653,5 & 100,0 & 9177,5 & 100,0 \\
\hline Машины, оборудование, транспортные средства & 2906,4 & 38,0 & 4250,0 & 46,4 \\
\hline Топливо, минеральное сырье, металлы & 901,3 & 11,8 & 1013,4 & 11,0 \\
\hline металлы и изделия из них & 751,1 & 9,8 & 812,0 & 8,8 \\
\hline Химические товары & 550,0 & 7,2 & 741,2 & 8,1 \\
\hline Древесина и целлюлозно-бумажные изделия & 124,5 & 1,5 & 168,6 & 1,8 \\
\hline Товары народного потребления & 3171,3 & 41,5 & 3004,3 & 32,7 \\
\hline пищевкусовые товары & 931,7 & 12,2 & 1086,6 & 11,8 \\
\hline промышленные товары народного потребления & 2239,6 & 29,3 & 1917,7 & 20,9 \\
\hline Прочие & 0,0 & 0,0 & 0,0 & 0,0 \\
\hline
\end{tabular}

Примечание. * Без учета импорта услуг, поставок бункерного топлива.

Источник: составлено по: [5].

Основной экспортный потенциал ДФО был сконцентрирован на территории Сахалинской области и Республики Саха (Якутия), хозяйствующие субъекты которых обеспечивали в 2011 г. 88,9\% дальневосточного экспорта (рuc. 7).

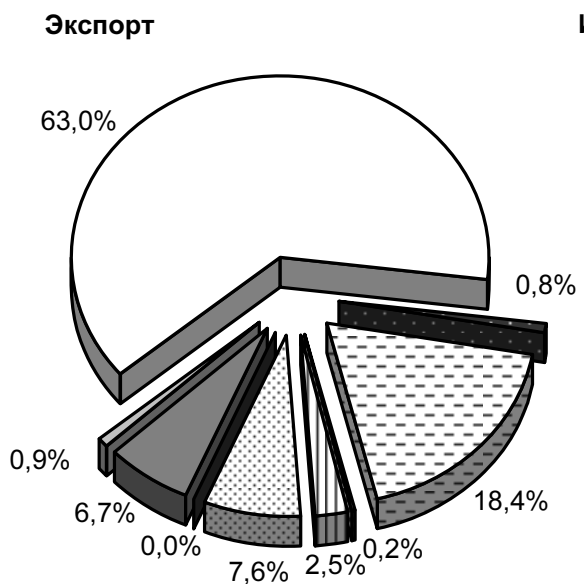

घРеспублика Саха (Якутия)

๑Приморский край

口Амурская область
Импорт

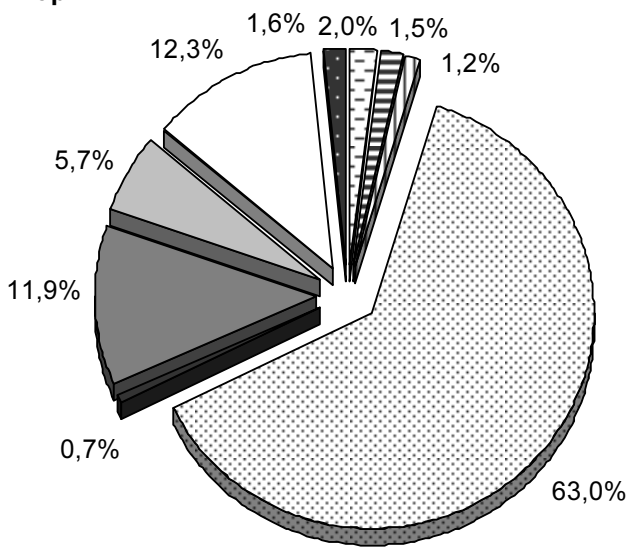

Puc. 7. Территориальная структура внешней торговли Дальнего Востока России в 2011 г. 
№ 22012

Среди дальневосточных субъектов РФ наибольший удельный вес во внешнеторговом обороте региона занимала Сахалинская область $(49,3 \%)$. Объем внешней торговли области в 2011 г. составил 16,7 млрд долл. и возрос по сравнению с 2010 г. на 31,3\%. Рост товарооборота был достигнут как за счет наращивания объемов экспорта (на $32,4 \%$ ), так и импорта (на 17,4\%).

Основной прирост стоимостных объемов экспорта был обеспечен продукцией ТЭК, которая лидирует в структуре экспорта Сахалинской области (нефть сырая, сжиженный природный газ, уголь) - 93,8\%. Высокие темпы роста были характерны для экспорта рыбопродукции и угля, физические объемы которых в 2011 г. увеличились почти в полтора раза. При этом физические объемы поставок нефти заметно снизились, природного газа - остались на прежнем уровне.

Наряду с Сахалинской областью лидирующие позиции во внешней торговле ДФО принадлежали Приморскому краю, на территории которого концентрировалось $63 \%$ дальневосточного импорта. Опережающие темпы роста импорта над экспортом края в 2011 г. еще более увеличили сложившееся ранее отрицательное сальдо торгового баланса, величина которого составила 3,9 млрд долл., что на 7,8\% выше относительно предыдущего периода.

В настоящее время на долю Приморского края приходится 51,5\% дальневосточного импорта машинотехнической продукции, 86,2\% - пищевкусовых товаров, 69,9\% - химической продукции, 80,7\% - промышленных товаров народного потребления (табл. 29).

Распределение объемов импорта основных видов продукции

Таблица 29 по территориям ДФО, 2011, \%

\begin{tabular}{l|c|c|c|c|c|c}
\hline Территория & $\begin{array}{c}\text { Машины, } \\
\text { оборудова- } \\
\text { ние, транс- } \\
\begin{array}{c}\text { портные } \\
\text { средства }\end{array}\end{array}$ & $\begin{array}{c}\text { Топливо, } \\
\text { мине- } \\
\text { сырьое } \\
\text { металлы }\end{array}$ & $\begin{array}{c}\text { Хи- } \\
\text { миче-- } \\
\text { ские } \\
\text { това- } \\
\text { ры }\end{array}$ & $\begin{array}{c}\text { Древесина } \\
\text { и целлю- } \\
\text { лозно-бу- } \\
\text { мажные } \\
\text { изделия }\end{array}$ & $\begin{array}{c}\text { Певку- } \\
\text { совые } \\
\text { товары }\end{array}$ & $\begin{array}{c}\text { Про- } \\
\text { мыш- } \\
\text { ленные } \\
\text { ТНП }\end{array}$ \\
\hline ДФО & 100,0 & 100,0 & 100,0 & 100,0 & 100,0 & 100,0 \\
\hline Республика Саха (Якутия) & 3,3 & 1,0 & 2,0 & 0,1 & 1,4 & 0,4 \\
\hline Камчатский край & 1,6 & 1,4 & 0,6 & 1,3 & 0,5 & 0,7 \\
\hline Приморский край & 51,5 & 44,5 & 69,9 & 83,9 & 86,2 & 80,7 \\
\hline Хабаровский край & 15,1 & 17,1 & 7,7 & 6,6 & 4,6 & 8,4 \\
\hline Амурская область & 7,3 & 3,9 & 4,7 & 3,0 & 2,5 & 5,8 \\
\hline Сахалинская область & 17,7 & 27,5 & 6,4 & 3,7 & 0,5 & 2,0 \\
\hline Магаданская область & 1,6 & 1,4 & 3,3 & 0,5 & 2,5 & 0,4 \\
\hline ЕАО & 0,6 & 0,6 & 0,2 & 0,4 & 1,5 & 0,5 \\
\hline ЧАО & 1,2 & 2,7 & 5,2 & 0,4 & 0,3 & 1,0 \\
\hline
\end{tabular}

Источник: составлено по: [5]. 
Положительной динамикой в 2011 г. характеризовалось развитие внешней торговли Республики Саха (Якутия). По сравнению с предыдущим периодом стоимостные объемы экспорта республики увеличились с 3,2 до 4,6 млрд долл., импорта - с 0,1 до 0,2 млрд долл.

Экспортный сектор республики традиционно тесно связан с освоением минерально-сырьевых ресурсов и, прежде всего, с разработкой алмазоносных месторождений и эксплуатацией угольных месторождений. Этим объясняется высокий удельный вес в товарной структуре экспорта продукции алмазного комплекса $(75,8 \%)$ и твердого топлива $(22,8 \%)$.

Товарная структура импорта Республики Саха (Якутия) в отличие от экспорта является более диверсифицированной. Наибольший удельный вес в импорте занимают машинотехническая продукция (74,9\%), предназначенная для реализации проектов в горнорудной промышленности и строительства инфраструктурных объектов на территории республики, и продукты питания (8\%).

В географической структуре внешней торговли ДФО в 2011 г., как и прежде, неизменно приоритетным оставалось тихоокеанское направление (рис. 9).

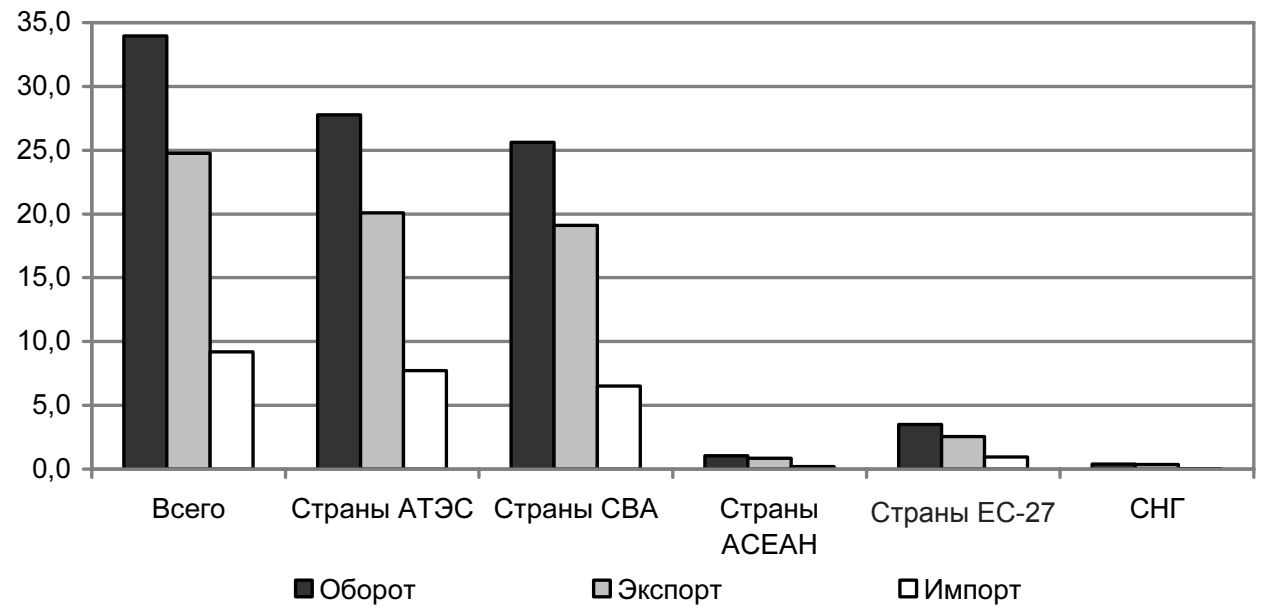

Puc. 9. Географическая направленность внешней торговли ДФО в 2011 г., млрд долл.

Традиционно главными торговыми партнерами российского Дальнего Востока являются страны «большой тройки» СВА.

С точки зрения объемов торговли с отдельными странами в 2011 г. основным торговым партнером Дальнего Востока России являлась Республика Корея. В 2011 г. ее доля во внешнеторговом обороте региона составляла $27,6 \%$, при этом южнокорейский рынок являлся основным 
№ 22012

потребителем дальневосточной продукции (32,5\% объема регионального экспорта).

Вторым по значению внешним рынком для Дальнего Востока России являлся Китай (24,9\% внешнеторгового оборота региона). В 2011 г. объем дальневосточного экспорта в китайском направлении составил 4,2 млрд долл., импорта - 4,3 млрд долл.

Значительный вклад в развитие торгово-экономического сотрудничества Дальнего Востока с зарубежными странами продолжает вносить Япония, на долю которой приходилось 22,9\% внешнеторгового оборота ДФО, в том числе $27,7 \%$ - экспорта и 9,9\% - импорта.

В целом изменения, произошедшие в 2011 г. в динамике, географической и товарной структуре внешней торговли Дальнего Востока, в значительной степени были обусловлены благоприятной конъюнктурой на рынке энергоносителей, металлов и лесных товаров, а также повышением внутрирегионального спроса на продукцию инвестиционного назначения.

\section{СПИСОК ЛИТЕРАТУРЫ}

1. Информация для ведения мониторинга социально-экономического положения РФ. М., 2012.

2. Итоги социально-экономического развития Приморского края. URL: http:// primorsky.ru/documents/departments_economrazv/yan_dekabr2011.pdf (дата обращения: 21.04.2012).

3. Литвинцева Г. П. Анализ ценовых диспропорций в российской экономике // Проблемы прогнозирования. 2002. № 4. С. 15-31.

4. Материалы официального сайта Ассоциации морских торговых портов. URL: http://www.morport.com/rus/publications/index.shtml/page2 (дата обращения: 30.04.2012).

5. Материалы официального сайта Дальневосточного таможенного управления Федеральной таможенной службы России. URL: http://dvtu.customs.ru/index. php?option=com_content\&view $=$ article $\&$ id $=8023:--16-31--2012-\&$ catid $=50$ :obzorspublic-cat\&Itemid=101 (дата обращения: 20.04.2012).

6. Материалы официального сайта Федеральной службы государственной статистики PФ. URL: www.gks.ru (дата обращения: 25.04.2012).

7. Материалы официального сайта Центрального банка PФ. URL: www.cbr.ru (дата обращения: 27.04.2012).

8. Материалы сайта. URL: http://investcafe.ru/blogs/webinars/posts/17535 (дата обращения: 29.04.2012).

9. Мау В. Экономика и политика в 2011 г.: глобальный кризис и поиск новой модели роста // Вопросы экономики. 2012. № 2. С. 4-26.

10. Об итогах социально-экономического развития РФ в 2011 г.: доклад Министерства экономического развития PФ. URL: http://www.economy.gov.ru/minec/main (дата обращения: 29.04.2012).

11. Об утверждении плана мероприятий по реализации в 2011-2015 гг. Концепции демографической политики Российской Федерации на период до 2025 г.: 
распоряжение Правительства РФ от 10.03.2011 г. № 367-p // Справочная система Консультант-Плюс.

12. Олег Кожемяко озвучил итоги развития региона в 2011 году. URL: http://www. teleport2001.ru/pravitelstvo-amurskoy-oblasti/2012/03/14/5491.html (дата обращения: 29.04.2012).

13. Основные показатели социально-экономического положения регионов Дальневосточного федерального округа в январе - декабре 2011 г. Хабаровск, 2012.

14. Прокапало О. М., Исаев А. Г., Суслов Д. В., Деваева Е. И., Котова Т. Е. Экономическая конъюнктура в Дальневосточном федеральном округе в 2010 г. // Пространственная экономика. 2011. № 2. С. 54-91.

15. Регионы России. Социально-экономические показатели. 2011: стат. сб. / Росстат. М., 2011.

16. Сервер Правительства Хабаровского края. URL: /http://gov.khabkrai.ru/invest2. nsf/pages/ru/Doc_280212.htm (дата обращения: 23.04.2012).

17. Социально-экономическое положение Дальневосточного федерального округа в 2011 году. М., 2012.

18. Социально-экономическое положение России. 2011. М., 2012.

19. Borts $G$. The Equalization of Returns and Regional Economic Growth // The American Economic Review. Vol. 50. № 3. Pp. 331-332. 